\title{
The Dynamics and Plasticity of Epigenetics in Diabetic Kidney Disease: Therapeutic Applications Vis-à-Vis
}

\author{
Feng-Chih Kuo ${ }^{1}\left(\mathbb{D}\right.$, Chia-Ter Chao ${ }^{2,3,4}$ (D) and Shih-Hua Lin ${ }^{5,6, *(\mathbb{D})}$ \\ 1 National Defense Medical Center, Department of Internal Medicine, Division of Endocrinology and \\ Metabolism, Tri-Service General Hospital, Taipei 114, Taiwan; shoummie@hotmail.com \\ 2 Department of Internal Medicine, Nephrology Division, National Taiwan University Hospital, \\ Taipei 100, Taiwan; b88401084@gmail.com \\ 3 Graduate Institute of Toxicology, National Taiwan University College of Medicine, Taipei 100, Taiwan \\ 4 Department of Internal Medicine, Nephrology Division, National Taiwan University College of Medicine, \\ Taipei 100, Taiwan \\ 5 National Defense Medical Center, Graduate Institute of Medical Sciences, Taipei 114, Taiwan \\ 6 National Defense Medical Center, Department of Internal Medicine, Nephrology Division, Taipei 114, Taiwan \\ * Correspondence: 1521116@gmail.com or 1521116@ndmctsgh.edu.tw
}

check for updates

Citation: Kuo, F.-C.; Chao, C.-T.; Lin, S.-H. The Dynamics and Plasticity of Epigenetics in Diabetic Kidney Disease: Therapeutic Applications Vis-à-Vis. Int. J. Mol. Sci. 2022, 23, 843 https://doi.org/10.3390/ ijms23020843

Academic Editor: Tadashi Yoshida

Received: 1 December 2021

Accepted: 11 January 2022

Published: 13 January 2022

Publisher's Note: MDPI stays neutral with regard to jurisdictional claims in published maps and institutional affiliations.

Copyright: () 2022 by the authors. Licensee MDPI, Basel, Switzerland. This article is an open access article distributed under the terms and conditions of the Creative Commons Attribution (CC BY) license (https:/ / creativecommons.org/licenses/by/ $4.0 /)$.

\begin{abstract}
Chronic kidney disease (CKD) refers to the phenomenon of progressive decline in the glomerular filtration rate accompanied by adverse consequences, including fluid retention, electrolyte imbalance, and an increased cardiovascular risk compared to those with normal renal function. The triggers for the irreversible renal function deterioration are multifactorial, and diabetes mellitus serves as a major contributor to the development of CKD, namely diabetic kidney disease (DKD). Recently, epigenetic dysregulation emerged as a pivotal player steering the progression of DKD, partly resulting from hyperglycemia-associated metabolic disturbances, rising oxidative stress, and/or uncontrolled inflammation. In this review, we describe the major epigenetic molecular mechanisms, followed by summarizing current understandings of the epigenetic alterations pertaining to DKD. We highlight the epigenetic regulatory processes involved in several crucial renal cell types: Mesangial cells, podocytes, tubular epithelia, and glomerular endothelial cells. Finally, we highlight epigenetic biomarkers and related therapeutic candidates that hold promising potential for the early detection of DKD and the amelioration of its progression.
\end{abstract}

Keywords: diabetic kidney disease; epigenetics; DNA methylation; histone modifications; noncoding RNAs

\section{Introduction}

Chronic kidney disease (CKD) is an instrumental risk factor for cardiovascular morbidities and has become the 12th leading cause of global death [1]. CKD confers a substantial economic burden on the existing healthcare system, since CKD incurs high medical costs, especially involving those with end-stage renal disease (ESRD) requiring long-term dialysis [2]. Overall, around $10 \%$ to $20 \%$ the global population has CKD, and the prevalence of CKD is still on the rise, particularly in developed countries [3]. The clinical presentations of CKD include proteinuria and a progressive loss of kidney function as measured by lowered estimated glomerular filtration rates (eGFRs). The ultrastructural alterations in kidneys of patients with CKD consist of glomerular or renal tubular injuries manifesting in podocyte foot process effacement, mesangial hypertrophy, extracellular matrix (ECM) accumulation, tubular epithelial-to-mesenchymal transition (EMT), and interstitial infiltration of inflammatory cells [4]. These pathological processes eventually induce irreversible renal fibrosis and clinically present as ESRD, with which patients exhaust most of their functional glomeruli. Therefore, timely discovery of the molecular pathogenesis of CKD with the administration of appropriate therapies can be crucial for retarding kidney dysfunction in patients with CKD. 
To prevent CKD progression, the optimized control of hyperglycemia, hypertension, and dyslipidemia is fundamental. The avoidance of repeated acute kidney injury (AKI), the use of reno-protective medications such as renin-angiotensin-aldosterone system blockers in patients with hypertension or sodium glucose cotransporter 2 inhibitors in patients with diabetes mellitus (DM), and the prompt correction of complications such as anemia, metabolic acidosis, and electrolyte imbalances, are important approaches for retarding CKD and reducing morbidity/mortality [5]. Other factors such as genetic susceptibility and epigenetic dysregulations also play a role in the progression of CKD [6].

Genome-wide association studies (GWAS) involving patients with CKD have identified > 250 genetic loci that correlated significantly with kidney function-related traits [7-9]. Recently, studies using the epigenome-wide next-generation sequencing and whole transcriptome analysis have pinpointed epigenetic alterations as important mechanisms underlying the interactions between the environment and the genome, and these alterations modify an individual's vulnerability and his/her risk for CKD development [10,11]. Since diabetes emerges as the main etiology of $C K D$, we review the existing literature regarding the epigenetic alterations inherent to diabetic kidney disease (DKD) and summarize cell-specific epigenetic mechanisms for major kidney cell types. Findings elaborated in this article are expected to facilitate individualized therapies based on the predominant cells involved in DKD pathology.

\section{Epigenetic Machineries: An Introduction}

Epigenetic regulation is defined as any process that influences transcription without changing DNA sequences. Three major epigenetic regulatory mechanisms have been delineated, including DNA methylation, chromatin modifications, and noncoding RNAs. They also interact with each other to orchestrate the complex epigenetic landscape associated with the regulation of nuclear 3D architectures, chromatin condensation, and DNA accessibility of enhancers, repressors, or promoter regions. Epigenetic regulation is dynamically influenced by an individual's surrounding environmental and can be inherited through cell divisions or between generations through the transmission of epigenetic markers to offspring [12,13]. The process of epigenetic regulation is also reversible or adjustable [14,15]. Epigenetic dysregulation has been identified as a major driving force for multiple diseases. Furthermore, epigenome-targeted therapies have been approved by the United States Food and Drug Association (FDA) for treating myelodysplastic syndrome and leukemia $[14,15]$. Recent studies have identified crucial epigenetic markers capable of impeding CKD progression. In the following sections, we will briefly describe the major epigenetic machineries.

\subsection{DNA Methylation}

DNA nucleotides consist of three subunits, the nucleobase, the five-carbon deoxyribose, and the phosphate group. There are four different DNA nucleobases: Guanine (G), adenine $(\mathrm{A})$, cytosine $(\mathrm{C})$, and thymine $(\mathrm{T})$. CpG sites are DNA regions where a cytosine nucleotide is followed by a guanine nucleotide along the $5^{\prime}$ to $3^{\prime}$ direction, while CpG islands refer to regions containing a high frequency of $\mathrm{CpG}$ sites. The cytosines of $\mathrm{CpG}$ sites can be methylated, forming 5-methylcytosines (5 mCs), and around 80-90\% CpG sites are methylated [16]. In the mammalian genome, approximately $70 \%$ of proximal promoters contain $\mathrm{CpG}$ islands near the transcription start sites $[17,18]$, and the presence of multiple methylated CpG sites in the promoter region suppresses gene expressions [19]. The promoter CpG islands of housekeeping genes are mostly hypomethylated, leading to a constitutive transcription. The maintenance of methylation is achieved by DNA methyltransferases 1 (DNMT1) via its strong preference for methylating CpG sites on the hemi-methylated DNA to counteract the dilutive effect of mitosis [20-22]. On the other hand, DNMT3A and DNMT3B generate de novo methylation, modifying methylation patterns [23-25]. The reversal for DNA methylation is achieved by changing $5 \mathrm{mC}$ to 5-hydroxy-methyl-cytosine $(5 \mathrm{hmC})$ by Ten-Eleven Translocation (TET) [26] (Figure 1A). 
Through concerted actions between DNMT and TET, the global DNA methylation status can be stably maintained and dynamically modulated during cellular proliferation, differentiation, and the stressed condition [27].

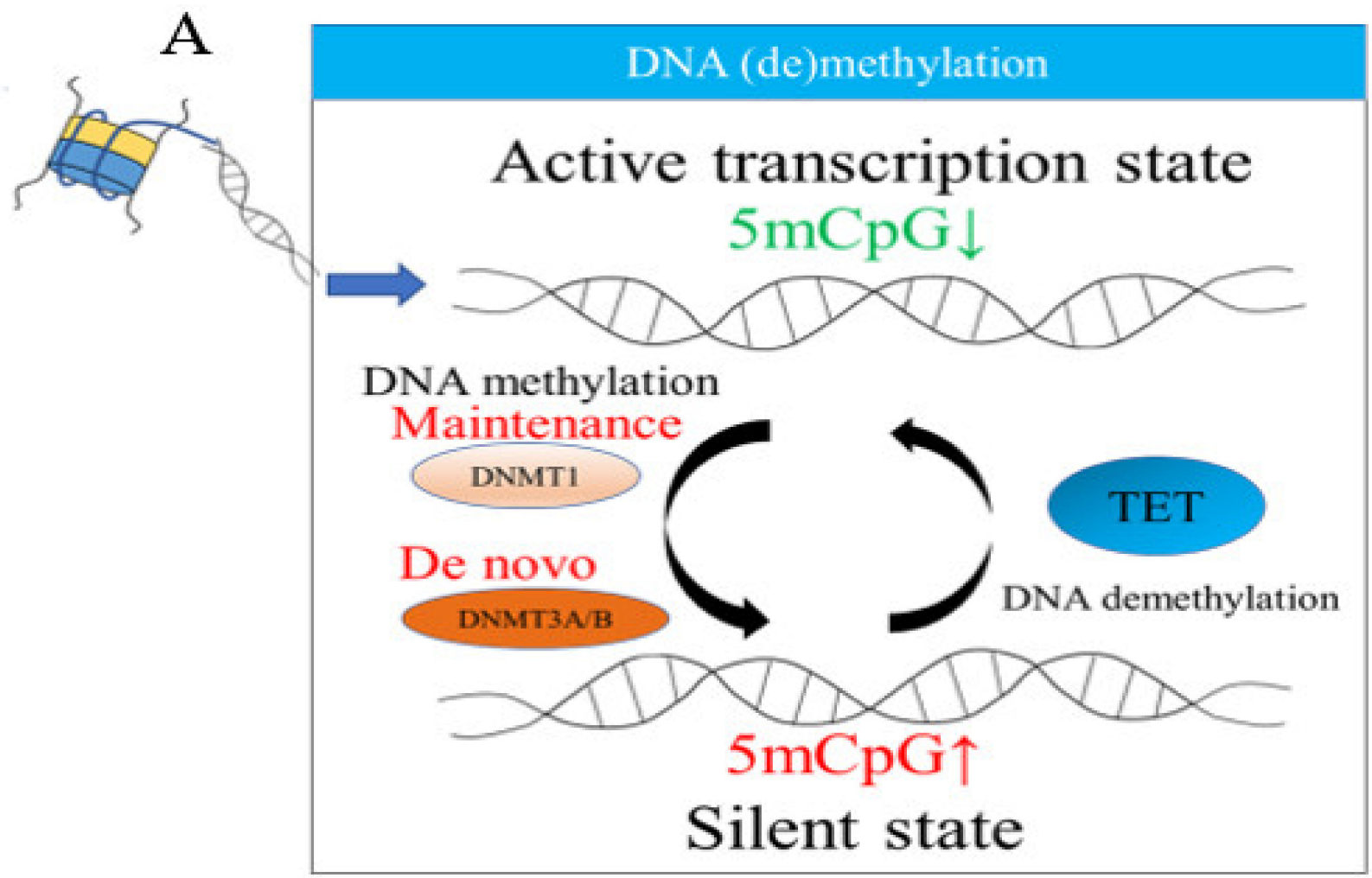

B

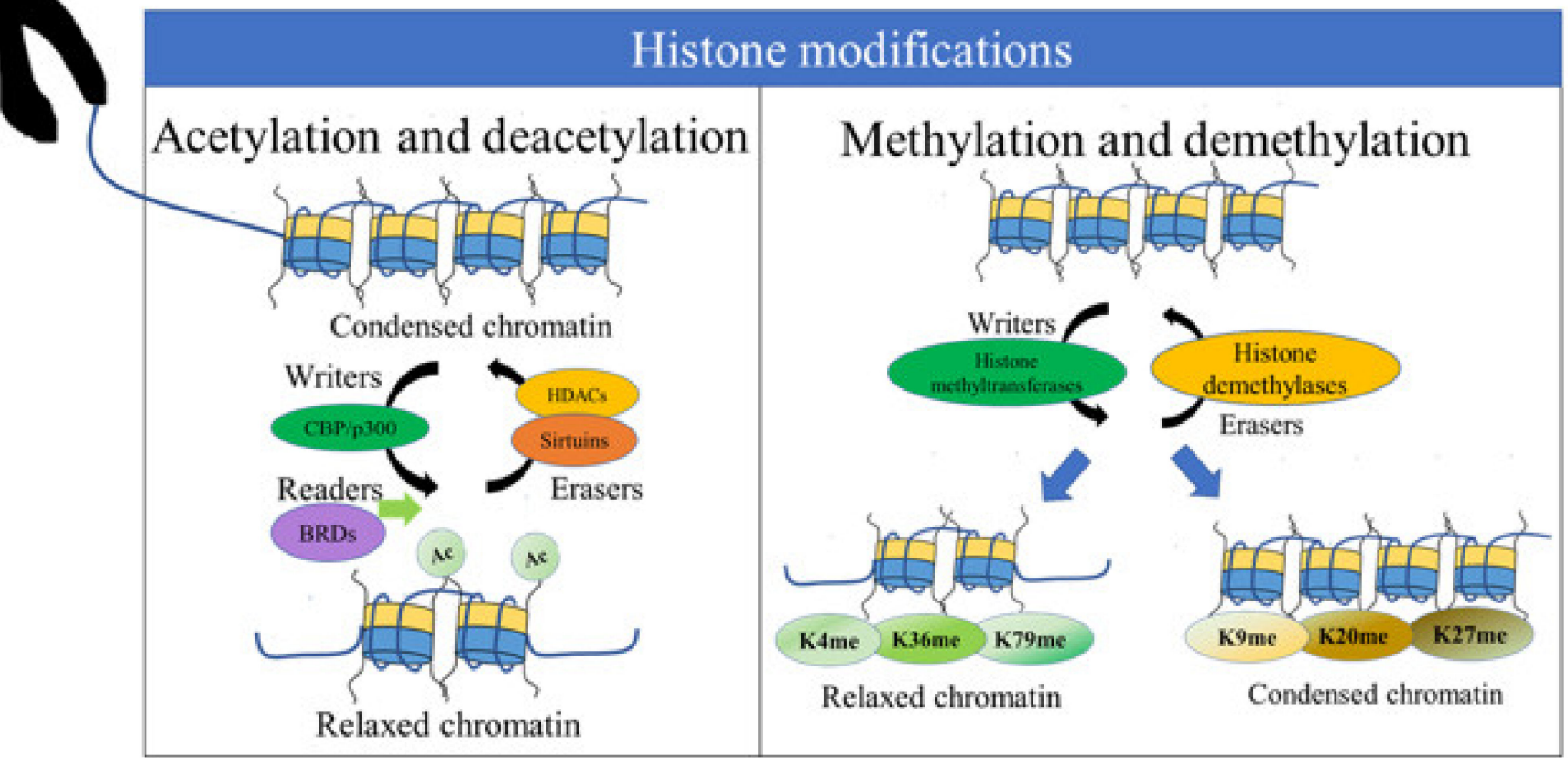

Figure 1. Cont. 


\section{Noncoding RNAs}
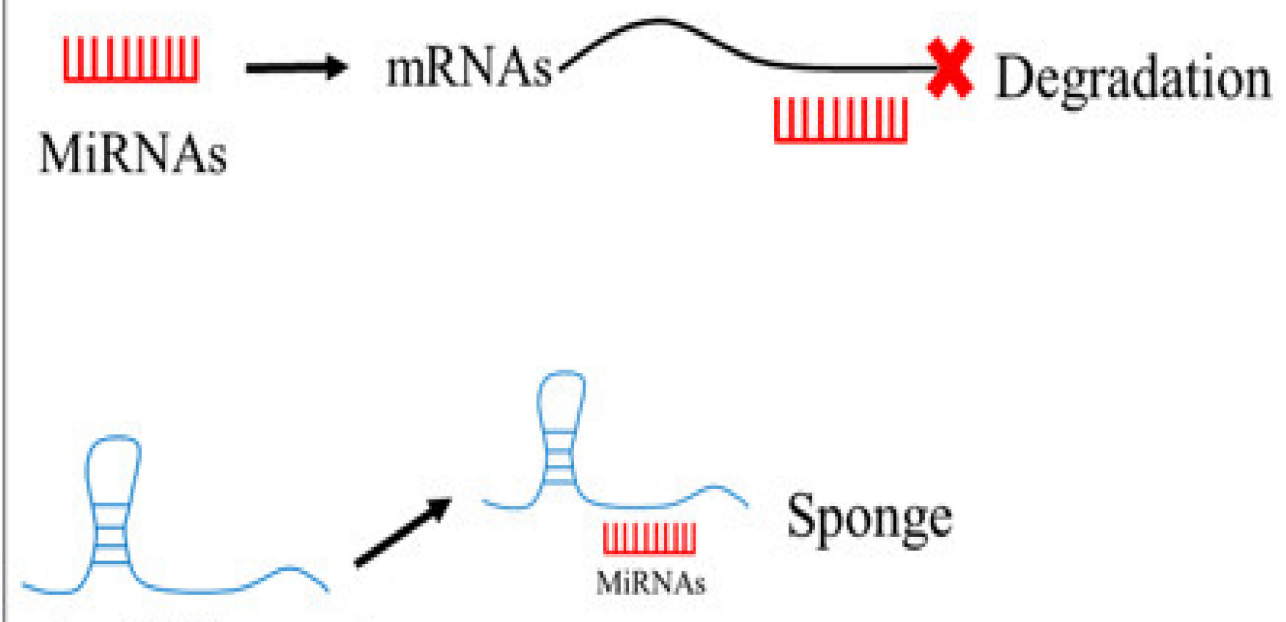

LncRNAs

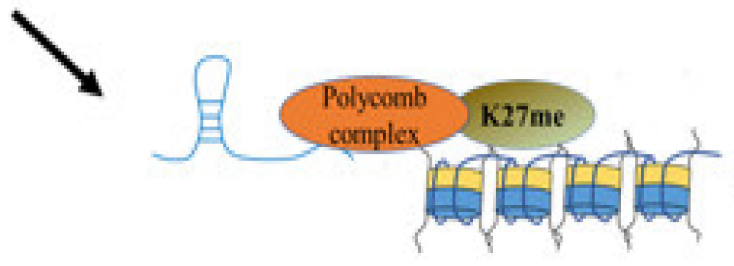

Histone modifications

Figure 1. Schematic presentations of three major epigenetic regulations. (A) DNA (de)methylation; (B) histone modifications; and (C) noncoding RNAs. Denote: 5 mCpG: A methyl cytosine followed by guanine along the 5' to 3' direction, DNMT: DNA methyltransferases, TET: Ten-Eleven Translocation, CBP: CREB-binding protein, HDACs: Histone deacetylases, BRDs: Bromodomain-containing proteins, Ac: Acetylation, miRNAs: MicroRNAs, and LncRNAs: Long noncoding RNAs.

\subsection{Histone Modifications}

Histones are basic amino acid-abundant proteins (lysine, abbreviation $\mathrm{K}$, and arginine, abbreviation $\mathrm{R}$ ) that wrap the double-helix DNA to create nucleosomes [28], which contain 4 'core' histones (H2A, H2B, H3, and H4). The H2A-H2B dimers and the H3-H4 tetramers form the histone octamers [29]. Nucleosomes are further wrapped into 30-nanometer fibers and tightly packed as chromatin. The interactions between histones, DNA, and nuclear proteins are altered via post-translational modifications (PTMs) involving lysine or arginine residues. Histone modifications are important epigenetic machineries influencing gene expressions, DNA repair, and chromatin condensation [30]. The major PTMs of histones include acetylation, methylation, phosphorylation, ubiquitylation, and SUMOylation [31] executed by histone modifiers such as writers (histone acetyltransferases and methyltransferases), erasers (deacetylases and demethylases), and readers (bromodomain-containing proteins (BRDs) such as BRD4) [10] (Figure 1B).

Histone acetyltransferases such as p300 and CREB-binding protein (CBP) catalyze histone acetylation to unwind chromatin and increase the accessibility of transcription factors or co-factors to promoters/enhancers to modulate gene expressions. Histone deacetylases (HDACs) and sirtuins remove acetylation marks of histones and act as co-repressors [32,33]. Histone methyltransferases or demethylases have variable functional roles in activating or repressing transcription through inducing different residue methylation and modification $[34,35]$. For example, lysine methylations at H3K4, H3K36, and H3K79 are associated 
with upregulation and enriched at transcriptionally active regions. On the other hand, methylation at $\mathrm{H} 3 \mathrm{~K} 9, \mathrm{H} 3 \mathrm{~K} 27$, and $\mathrm{H} 4 \mathrm{~K} 20$ repress gene repressions and are enriched at repressed regions [34,36]. The epigenetic readers of BRDs recognize acetylated lysine residues and regulate protein-protein interactions to activate transcription [37]. These histone modifiers jointly modulate transcription, but their interactions are still incompletely understood.

\subsection{Noncoding RNAs}

Noncoding RNAs are RNA molecules not translated into proteins. They can be divided into small and long noncoding RNAs based on total nucleotide counts. Small noncoding RNAs have fewer than 200 nucleotides and include three classes, microRNAs (miRNAs), small interfering RNAs (siRNAs), and piwi-interacting RNAs (piRNAs). MiRNAs are small single-strand non-coding RNAs (about 22 nucleotides) that function to silence target messenger RNAs (mRNAs) via base-pairing with complementary sequences [38] (Figure 1C). siRNAs are double-strand non-coding RNAs (about 20-24 base pairs) that work similarly to miRNAs via degrading mRNAs [39]. piRNAs have around 26-31 nucleotides and act by forming piRNA complexes with piwi-subfamily Argonaute proteins [40,41].

Long non-coding RNAs (lncRNAs) have more than 200 nucleotides with secondary or tertiary structures, serving as scaffolds for interactions between RNAs, DNAs, and proteins. LncRNAs are expressed in relatively low levels with tissue specificity and exhibit multiple regulatory mechanisms including sponging miRNAs or inducing histone modifications [42] (Figure 1C). The functions of many lncRNAs are still uncertain and require further investigation.

\section{DKD: An Overview}

Type 1 and type 2 DM are the main etiologies for CKD development. Approximately $45 \%$ of cases with ESRD result from DKD [43], and 20-40\% of patients with type 2 DM have nephropathy depending upon geographic areas [44]. Hyperglycemia is an important form of metabolic stress capable of modifying epigenetic processes [45]. Many studies evaluate epigenetic modifications in DKD; in the following section, we summarize reports investigating the pathogenic roles of epigenetic regulation associated with DKD.

\subsection{DNA Methylation in DKD}

Prior studies used whole blood- or mononuclear cell-derived DNAs for performing epigenome-wide association studies (EWAS). Bell et al. conducted a case-control study of 192 Irish type 1 diabetic patients to compare DNA methylomes between individuals with and without nephropathy. They identified $19 \mathrm{CpG}$ sites associated with the time to DKD development [46]. Similarly, studies involving patients with type 1 DM used the Illumine Infinium HumanMethylation 450 array and identified differentially methylated genes, especially those altering mitochondrial function [47]. In the Diabetes Control and Complications Trial (DCCT) and the Epidemiology of Diabetes Interventions and Complications (EDIC) studies, investigators used whole blood- and monocytes-derived DNA for comparing global methylomes between those with and without diabetic complications [48]. They identified 12 differentially methylated loci common to both whole blood- and monocyte-derived DNA, including hypomethylation of TXNIP (thioredoxininteracting protein involved in oxidative stress and apoptosis) [49]. Their results provide strong evidence that hyperglycemic-mediated DNA methylation creates metabolic memory related to the DKD pathogenesis.

EWAS using whole blood-derived DNA has also been performed in patients with type 2 diabetes. Several CpG hypomethylation sites were found to correlate with genes involved in DKD [50]. After combining methylomes, transcriptomes, and single nucleotide polymorphisms (SNPs) from 500 patients with DKD from the Chronic Renal Insufficiency Cohort, the authors found 40 differentially methylated and expressed loci prioritized, exhibiting associations with DKD phenotypes, and these loci were functionally enriched for inflammation, apoptosis, and complement activation [51]. Another large study analyzing 
methylomes from the Atherosclerosis Risk in Communities cohort and the Framingham Heart study cohort revealed 19 CpG sites associated with eGFR, among which five were associated with biopsy-proven renal fibrosis; these findings indicate that changes in DNA methylation occurred in the kidney cortex [52]. Similarly, aberrant DNA methylation was also demonstrable in proximal tubular epithelial cells collected from type 2 diabetic animals, and these genes were functionally enriched for mitochondrial biogenesis [53]. Collectively, hyperglycemia-induced DNA methylation changes are both evident in patients with DKD associated with type 1 and type $2 \mathrm{DM}$ and affect not only circulating blood cells but also kidney cells.

Changes in DNMT1 levels in whole blood or mononuclear cells from patients with DKD also participate in its pathogenesis. DNMT1 levels were found to increase in the peripheral blood mononuclear cells (PBMCs) of patients with DKD and a higher inflammation severity [54]. Another study also indicated that DNMT1 activity increased during DKD [55]. A higher DNA methylation ratio of let-7a-3 promoter with increased expressions of UHRF1 and DNMT1 was found in those with DKD [55], suggesting that loss of let-7a-3 might restore the expression of its target, UHRF1, which enhanced the binding of DNMT1 to hemi-methylated DNAs [56]. The increased DNMT1 levels in circulating blood cells might influence multiple organs or systems, since DNMT1 aggravated retinal damages in diabetic mice [57].

The correlation between gene methylation levels and clinical DKD markers such as albuminuria, serum homocysteine [58], and insulin-like growth factor binding protein-1 (IGFBP-1) [59] also warrants discussion. Higher albuminuria levels were associated with hypomethylation of TIMP-2 and AKR1B1 [60]. Increased serum homocysteine was also observed in patients with DKD, and the methylene tetrahydrofolate reductase (MTHFR) gene, which was involved in homocysteine metabolism, had higher promoter methylation levels [61]. Patients with type 1 DM and DKD had higher circulating IGFBP-1 and lower IGFBP1 methylation levels [62], suggesting that IGFBP-1 participated in DKD development. In addition, the connective tissue growth factor (CTGF) is an inducer for extracellular matrix accumulation and correlates with DKD pathogenesis [63]. Interestingly, lower CTGF DNA methylation levels and increased CTGF protein were associated with albuminuria and eGFR decline in patients with DKD [64], compatible with results from cellular studies showing that high glucose-treated mesangial cells exhibited hypomethylation of the CTGF promoter and increased CTGF expressions [65]. Moreover, the RAS protein activator-like 1 (RASAL1) encoded by Rasal1 inhibits renal fibrosis by switching off RAS activity [66]. Using kidneys from unilateral ureteral obstruction (UUO) and DKD mice and primary renal fibroblasts, hypermethylation of the Rasal1 promoter contributed to fibroblast activation and kidney fibrosis progression [67]. Overall, these results support the fact that multiple signaling pathways are dynamically regulated by DNA methylation, contributing to DKD progression. We summarize these results in Table 1.

Table 1. DNA methylation in diabetic kidney disease.

\begin{tabular}{ccc}
\hline Study Design (Reference) & Main Cells or Tissue Samples & Epigenetic Changes (Mechanisms Involved) \\
\hline $\begin{array}{c}\text { A case-control study of 192 Irish T1D } \\
\text { patients. Cases had T1D and } \\
\text { nephropathy whereas controls had T1D } \\
\text { without renal disease [46] }\end{array}$ & Whole blood & $\begin{array}{c}\text { Methylation state of 19 CpG sites associated with } \\
\text { risk of diabetic kidney disease (EWAS, time to } \\
\text { diabetic kidney disease) }\end{array}$ \\
\hline $\begin{array}{c}\text { A case-control association study }(n=196 \\
\text { T1DM and diabetic kidney disease vs. } \\
n=246 \text { without renal disease) [4] }\end{array}$ & Whole blood & $\begin{array}{c}\text { PMPCB, TSFM, and AUH with differential } \\
\text { methylation at multiple CpG sites (EWAS, } \\
\text { mitochondria dysfunction) }\end{array}$ \\
$\begin{array}{c}\text { DNA from Pre-DM }(n=11) \text { at baseline } \\
\text { and at their transition to T2DM [50] }\end{array}$ & Whole blood & $\begin{array}{r}\text { 694 CpG sites hypomethylated and 174 CpG sites } \\
\text { hypermethylated (EWAS, glucose/lipid } \\
\text { metabolism, and inflammation) }\end{array}$ \\
\hline
\end{tabular}


Table 1. Cont.

\begin{tabular}{|c|c|c|}
\hline Study Design (Reference) & Main Cells or Tissue Samples & Epigenetic Changes (Mechanisms Involved) \\
\hline $\begin{array}{l}\text { Genome-wide methylome in } 500 \text { subjects } \\
\text { with DKD from the Chronic Renal } \\
\text { Insufficiency Cohort [51] }\end{array}$ & Whole blood & $\begin{array}{l}\text { Prioritized } 40 \text { loci, methylation and } \\
\text { gene-expression changes likely mediate the } \\
\text { genotype effect on kidney disease development } \\
\text { (EWAS, inflammation } \uparrow \text { ) }\end{array}$ \\
\hline $\begin{array}{l}60 \text { individuals, with } 20 \text { cases in the } \\
\text { control, DM and DKD groups } \\
\text { respectively [55] }\end{array}$ & Whole blood & $\begin{array}{l}\text { Higher methylation ratio of the let-7a-3 promoter } \\
\text { (UHRF1 } \uparrow \text { and DNMT1 } \uparrow \text { ) }\end{array}$ \\
\hline $\begin{array}{l}\text { Two groups of patients based on albumin } \\
\text { excretion as patients with }(n=69) \text { and } \\
\text { without DKD }(n=27)[60]\end{array}$ & Whole blood & $\begin{array}{c}\text { Hypomethylation of TIMP-2 and AKR1B1 } \\
\text { genes (albuminuria } \uparrow \text { ) }\end{array}$ \\
\hline $\begin{array}{l}24 \text { cases of simple diabetes group; } \\
34 \text { cases of early DKD group; } 27 \text { cases of } \\
\text { clinical DKD group; and } 30 \text { healthy } \\
\text { controls [61] }\end{array}$ & Whole blood & $\begin{array}{l}\text { Higher MTHFR promoter methylation in clinical } \\
\text { diabetic kidney disease group (homocysteine } \uparrow \text { ) }\end{array}$ \\
\hline $\begin{array}{l}778 \text { Swedish individuals, including T1D } \\
\text { patients with or without DKD and } \\
\text { subjects with normal glucose } \\
\text { tolerance [62] }\end{array}$ & Whole blood & $\begin{array}{l}\text { DNA methylation levels in the IGFBP1 } \\
\text { gene } \downarrow \text { (circulating IGFBP-1个) }\end{array}$ \\
\hline $\begin{array}{l}\text { Non-diabetes control }(n=29) \text {, diabetes } \\
\text { without nephropathy }(n=37), \text { and } \\
\text { diabetes with nephropathy }(n=38)[64]\end{array}$ & Whole blood & $\begin{array}{l}\text { Lower CTGF methylation levels } \\
\quad(\mathrm{ECM} \uparrow, \text { albuminuria } \uparrow)\end{array}$ \\
\hline $\begin{array}{l}32 \text { cases (conventional therapy with } \\
\text { retinopathy or albuminuria) vs. } \\
31 \text { subjects (intensive therapy without } \\
\text { complication), human monocytes [48] }\end{array}$ & $\begin{array}{l}\text { Whole blood isolated at EDIC } \\
\text { Study year } 10 \text { and monocytes } \\
\text { during year 16-17. }\end{array}$ & $\begin{array}{c}12 \text { differentially methylated loci were common in } \\
\text { both whole blood and monocytes, including } \\
\text { hypomethylation of TXNIP (EWAS, } \\
\text { oxidative stress } \uparrow \text { ) }\end{array}$ \\
\hline $\begin{array}{l}\text { Mononuclear cells in DKD patients, } \\
\text { diabetic mice, and cultured diabetic } \\
\text { mononuclear cells [54] }\end{array}$ & Immune (mononuclear) cells & DNMT1 $\uparrow$ (inflammation $\uparrow$ ) \\
\hline $\begin{array}{c}\text { Whole-blood DNA methylation of } 2264 \\
\text { (586 DM) Atherosclerosis Risk in } \\
\text { Communities and } 2595 \text { (394 DM) } \\
\text { Framingham Heart Study } \\
\text { participants [52] }\end{array}$ & Whole blood and renal biopsy & $\begin{array}{c}\text { Lead CpGs at PTPN6/PHB2, ANKRD11, and } \\
\text { TNRC18 map to active enhancers in kidney } \\
\text { cortex (EWAS, fibrosis } \uparrow)\end{array}$ \\
\hline $\begin{array}{l}\text { UUO and DKD kidney mice model, } \\
\text { primary renal fibroblast [67] }\end{array}$ & $\begin{array}{l}\text { Kidney of mice model, primary } \\
\text { renal fibroblast }\end{array}$ & $\begin{array}{l}\text { Hypermethylation of the Rasal1 } \\
\text { promoter (fibrosis } \uparrow \text { ) }\end{array}$ \\
\hline $\begin{array}{l}\text { High glucose treated human glomerular } \\
\text { mesangial cells [65] }\end{array}$ & Mesangial cell & Reduced methylation of $C T G F$ promoter (ECM $\uparrow)$ \\
\hline Proximal tubules of $d b / d b$ mice [53] & Tubular epithelia & $\begin{array}{l}\text { Aberrant hypomethylation of Agt, Abcc4, } \\
\text { Cyp4a10, Glut5, and Met and hypermethylation } \\
\text { of Kif20b, Cldn18, and Slco1a1 } \\
\text { (mitochondria dysfunction) }\end{array}$ \\
\hline
\end{tabular}

Denote: T1D: Type 1 diabetic, EWAS: Epigenome-wide association studies, DM: Diabetes mellitus, DKD: Diabetic kidney disease, ECM: Extracellular matrix, EDIC: Epidemiology of Diabetes Interventions and Complications, and UUO: Unilateral ureteral obstruction. Symbols: $\uparrow$ refers to increase; $\downarrow$ refers to decrease.

\subsection{Histone Modifications in $D K D$}

Hyperglycemia-mediated epigenetic processes and metabolic memory are not limited to DNA methylation. A case-control study aimed to analyze the promoter enrichment for H3 lysine-9 acetylation (H3K9ac), H3 lysine-4 trimethylation (H3K4me3), and H3K9me2 in monocytes and lymphocytes from EDIC and DCCT participants [68]. Notably, monocytes from cases presenting with increased H3K9ac enrichment (active chromatin mark) in promotor regions were significantly associated with mean $\mathrm{HbA1c}$ levels. More than 15 genes were linked to the top 38 hyperacetylated promoters, associated with the nuclear factor- $\mathrm{kB}$ 
(NF-kB) inflammatory pathway and diabetes complications. These results indicate that the active histone posttranslational modification H3K9ac is an important epigenetic mark for metabolic memory in patients with type 1 diabetes. Several studies also pointed out that histone acetyltransferases (such as p300 and CBP) and deacetylases (such as HDACs and SIRT1) participated in the epigenetic regulation of DKD. Using a diabetic mice model and transforming growth factor (TGF)- $\beta 1$-treated mesangial cell lines, p300- and CBP-mediated $\mathrm{H} 3$ acetylation (such as H3K9/14 acetylation) were enriched at PAI-1 and p21 promoters [69], and the acetylation of transcription factor Ets-1 was induced by p300 [70]. Ets-1 subsequently sustained the expressions of miR-192 [71]. Plasminogen activator inhibitor-1 (PAI-1), p21, and miR-192 were all involved in glomerular hypertrophy and extracellular matrix accumulation [72-74], contributing to DKD pathogenesis.

Regarding histone deacetylases, increased HDAC4 and HDAC9 were found in the renal biopsy specimens of patients with DKD and diabetic animals $[75,76]$. Their roles in high glucose-induced reactive oxygen species (ROS) generation, podocyte apoptosis, and inflammation were also demonstrated $[75,76]$. Downregulation of Sirt1 was observed in the proximal tubules (PTs) of diabetic mice, and the protective roles of PT Sirt1 in glomerular podocytes were further disclosed using the PT-specific SIRT1 transgenic and Sirt1 knockout mice. These results highlighted the intricate crosstalk between PT cells and podocytes [77]. On the other hand, apelin-13 could attenuate the development of DKD via inhibiting histone hyperacetylation and suppressing inflammatory factors [78]. In aggregate, these results suggest that histone acetyltransferases and deacetylases actively engage in the pathogenesis of DKD.

Studies on histone methyltransferases (SET7/9, SUV39H1, and EZH2) reveal their involvement in DKD progression. Reports of TGF- $\beta 1$ or high glucose-induced extracellular matrix (ECM) gene expressions in rat mesangial cells revealed that SET7/9 (a lysine methyltransferase for H3K4) and active chromatin marks (H3K4me1, H3K4me2, and $\mathrm{H} 3 \mathrm{~K} 4 \mathrm{me} 3$ ) were increased and recruited to their promoter regions [79]. Moreover, in the kidneys of type 2 diabetic mice, an increase in X-box binding protein 1 (XBP1s), an endoplasmic reticulum (ER) stress-inducible transcription factor, promoted the expression of SET7/9 with augmented recruitments of SET7/9 and H3K4me1 on the promoters of monocyte chemoattractant protein-1 (MCP-1) [80]. SUV39H1 catalyzing the trimethylation of histone $\mathrm{H} 3$ lysine 9 (H3K9me3) also correlated with mesangial dysfunction or tubular inflammation in the setting of DKD. Downregulation of SUV39H1 reduced $\mathrm{H} 3 \mathrm{~K} 9 \mathrm{me} 3$ recruitment on the promoters of fibronectin and p21 in high glucosetreated mesangial cells, increasing their expressions and stimulating mesangial hypertrophy [81]. Likewise, greater and prolonged glucose stimulation of human PT cells suppressed SUV39H1 and H3K9me3 with increased expressions of IL-6 and MCP-1 [82]. SET7 / 9 and SUV39H1 expressions could be modulated by H2AK119 and H2BK120 monoubiquitination in diabetic kidneys [83]. EZH2 catalyzing the trimethylation of histone H3 lysine 7 (H3K27me3) was shown to protect against DKD progression. Pharmacologic or genetic depletion of EZH2 in diabetic kidneys or high glucose cultured podocytes could decrease H3K27me3 and induce TXNIP expression, augmenting oxidative stress and proteinuria [84]. Downregulation of H3K27me3 was observed in podocytes from patients with DKD, and EZH2 knockdown in podocytes promoted its dedifferentiation while restoring Notch ligand Jagged-1 expression [85]. In mesangial cells and rodent DKD model, decreased enrichment of Ezh2 and H3K27me3 at the promoters of ECM or inflammatory genes were associated with mesangial dysfunction [86]. Taken together, the post-translational modifications of histones are heavily involved in the development of DKD. We summarize these findings in Table 2. 
Table 2. Histone modifications in diabetic kidney disease.

\begin{tabular}{|c|c|c|}
\hline Study Design (Reference) & Main Cells or Tissue Samples & Epigenetic Changes (Mechanisms Involved) \\
\hline $\begin{array}{l}30 \text { DCCT conventional treatment subjects } \\
\text { (cases: mean HbA1c level }>9.1 \% \text { with } \\
\text { retinopathy or nephropathy by EDIC } \\
\text { year } 10 \text { of follow-up) versus } 30 \text { intensive } \\
\text { treatment subjects (controls: mean HbA1c } \\
\text { level }<7.3 \% \text { without complications) [68] }\end{array}$ & $\begin{array}{l}\text { Blood monocytes } \\
\text { and lymphocytes }\end{array}$ & $\begin{array}{l}\text { Promoter regions with enrichment } \\
\text { H3K9Ac } \uparrow \text { (inflammation } \uparrow \text { ) }\end{array}$ \\
\hline$d b / d b$ mice $[80]$ & Kidneys of $d b / d b$ mice & $\begin{array}{l}\text { SET7/9 and the recruitment to promoters } \uparrow, \\
\text { H3K4me1 recruitment at MCP-1 promoters } \uparrow \\
\text { (ER stress } \uparrow \text { ) }\end{array}$ \\
\hline $\begin{array}{c}\text { Glomeruli from diabetic mice, TGF- } \beta 1 \text { or } \\
\text { high glucose treated rat mesangial } \\
\text { cell [69] }\end{array}$ & Mesangial cell & $\begin{array}{c}\text { H3K9/14 acetylation } \uparrow \text { and } \mathrm{CBP} / \mathrm{p} 300 \\
\text { occupancies } \uparrow \text { at the PAI- } 1 \text { and } \mathrm{P} 21 \\
\text { promoters (ECM } \uparrow \text { ) }\end{array}$ \\
\hline $\begin{array}{c}\text { Diabetic } d b / d b \text { mice, TGF- } \beta \text { treated mouse } \\
\text { mesangial cell [70] }\end{array}$ & Mesangial cell & $\begin{array}{c}\text { Akt and p300个, acetylation of Ets-1 and histone } \\
\qquad \mathrm{H} 3 \uparrow(\mathrm{ECM} \uparrow)\end{array}$ \\
\hline $\begin{array}{c}\text { Type } 1 \text { diabetic model, high glucose- or } \\
\text { sodium butyrate-treated mesangial cells } \\
\text { in the presence or absence of } \\
\text { apelin-13 [78] }\end{array}$ & Mesangial cell & $\begin{array}{c}\text { Apelin-13 treatment inhibited histone } \\
\text { hyperacetylation by upregulation of histone } \\
\text { deacetylase (inflammation) }\end{array}$ \\
\hline $\begin{array}{l}\text { TGF- } \beta 1 \text { treated rat mesangial cell under } \\
\text { high or normal glucose [79] }\end{array}$ & Mesangial cell & $\begin{array}{c}\text { SET7/9 } \uparrow \text { at promoters of the ECM-associated } \\
\text { genes (ECM } \uparrow)\end{array}$ \\
\hline $\begin{array}{l}\text { High glucose treated mouse } \\
\text { mesangial [81] }\end{array}$ & Mesangial cell & $\begin{array}{l}\text { Suv39h1 } \downarrow, \mathrm{H} 3 \mathrm{~K} 9 \mathrm{me} 3 \text { levels } \downarrow \text { at the promoters of } \\
\text { fibronectin and p21(WAF1) genes (ECM } \uparrow)\end{array}$ \\
\hline Type 1 diabetic rat kidney [83] & Mesangial cell & $\mathrm{H} 2 \mathrm{AK} 119 \mathrm{Ub} \downarrow$ and $\mathrm{H} 2 \mathrm{BK} 120 \mathrm{Ub} \downarrow(\mathrm{ECM} \uparrow)$ \\
\hline $\begin{array}{l}\text { STZ-induced diabetic rats, TGF- } \beta \text { treated } \\
\text { rat, mouse, and human mesangial } \\
\text { cells [86] }\end{array}$ & Mesangial cell & $\begin{array}{l}\operatorname{miR}-101 \mathrm{~b} \uparrow / \text { Ezh2 } \downarrow \text {, Jmjd } 3 \text { and Utx } \uparrow / \mathrm{H} 3 \mathrm{~K} 27 \mathrm{me} 3 \downarrow \\
\text { (mesangial dysfunction, ECM } \uparrow \text { ) }\end{array}$ \\
\hline $\begin{array}{l}\text { Kidney tissues from diabetic } d b / d b \text { mice } \\
\text { and patients with DKD, high } \\
\text { glucose-treated mouse podocytes [75] }\end{array}$ & Podocyte & $\begin{array}{l}\text { HDAC9 } \uparrow \text { (oxidative stress, apoptosis, } \\
\text { and inflammation } \uparrow \text { ) }\end{array}$ \\
\hline $\begin{array}{l}\text { Human DKD renal biopsy, STZ-induced } \\
\text { diabetic rats, diabetic } d b / d b \text { mice, glucose, } \\
\text { or AGEs or TGF- } \beta \text { treated podocyte [76] }\end{array}$ & Podocyte & HDAC4 $\uparrow$ (inflammation $\uparrow)$ \\
\hline $\begin{array}{l}\text { Kidneys of diabetic rats, high glucose } \\
\text { treated podocytes [84] }\end{array}$ & Podocyte & EZH2 expression $\downarrow$ (oxidative stress $\uparrow$ ) \\
\hline $\begin{array}{c}\text { Human FSGS or DKD renal biopsy, } \\
\text { animal studies of adriamycin } \\
\text { nephrotoxicity, subtotal nephrectomy and } \\
\text { diabetic } d b / d b \text { mice, mouse and human } \\
\text { podocytes [ } 85]\end{array}$ & Podocyte & H3K27me3 $\downarrow$ (podocyte dedifferentiation $\uparrow$ ) \\
\hline $\begin{array}{l}\text { STZ-induced or obese-type }(d b / d b) \\
\text { diabetic mice, high glucose treated } \\
\text { human-derived renal epithelial cells [77] }\end{array}$ & Tubular epithelia & Sirt $1 \downarrow$ (podocyte foot process effacement $\uparrow$ ) \\
\hline $\begin{array}{l}\text { Human DKD renal biopsy compared to } \\
\text { non-DKD minimal change diseases, high } \\
\text { glucose treated human proximal tubular } \\
\text { epithelial cells [82] }\end{array}$ & Tubular epithelia & $\begin{array}{c}\text { SUV39H1个 (DM renal tubules), SUV39H1 } \downarrow \\
\text { (greater glucose and prolonged stimulation in } \\
\text { cells) (inflammation } \uparrow)\end{array}$ \\
\hline $\begin{array}{l}\text { Denote: DC } \\
\text { Complicatio } \\
\text { disease, AC } \\
\uparrow \text { refers to ir }\end{array}$ & $\begin{array}{l}\text { Diabetes Control and Complication } \\
\text { R: Endoplasmic reticulum, ECM: Ex } \\
\text { Advanced glycation end products } \\
\text { se; } \downarrow \text { refers to decrease. }\end{array}$ & $\begin{array}{l}\text { ial, EDIC: Epidemiology of Diabetes Interventions and } \\
\text { ellular matrix, STZ: Streptozotocin, DKD: Diabetic kidney } \\
\text { d FSGS: Focal segmental glomerulosclerosis. Symbols }\end{array}$ \\
\hline
\end{tabular}

Kidney tissues from diabetic $d b / d b$ mice and patients with DKD, high

glucose-treated mouse podocytes [75]

Human DKD renal biopsy, STZ-induced diabetic rats, diabetic $d b / d b$ mice, glucose, or AGEs or TGF- $\beta$ treated podocyte [76]
HDAC9 (oxidative stress, apoptosis, and inflammation $\uparrow$ )

\begin{tabular}{|c|c|c|}
\hline $\begin{array}{c}\text { Glomeruli from diabetic mice, TGF- } \beta 1 \text { or } \\
\text { high glucose treated rat mesangial } \\
\text { cell [69] }\end{array}$ & Mesangial cell & $\begin{array}{c}\text { H3K9/14 acetylation } \uparrow \text { and } \mathrm{CBP} / \mathrm{p} 300 \\
\text { occupancies } \uparrow \text { at the PAI- } 1 \text { and P21 } \\
\text { promoters (ECM } \uparrow \text { ) }\end{array}$ \\
\hline $\begin{array}{c}\text { Diabetic } d b / d b \text { mice, TGF- } \beta \text { treated mouse } \\
\text { mesangial cell [70] }\end{array}$ & Mesangial cell & $\begin{array}{l}\text { Akt and p300个, acetylation of Ets-1 and histone } \\
\qquad \mathrm{H} 3 \uparrow(\mathrm{ECM} \uparrow)\end{array}$ \\
\hline $\begin{array}{c}\text { Type } 1 \text { diabetic model, high glucose- or } \\
\text { sodium butyrate-treated mesangial cells } \\
\text { in the presence or absence of } \\
\text { apelin-13 [78] }\end{array}$ & Mesangial cell & $\begin{array}{c}\text { Apelin-13 treatment inhibited histone } \\
\text { hyperacetylation by upregulation of histone } \\
\text { deacetylase (inflammation) }\end{array}$ \\
\hline $\begin{array}{l}\text { TGF- } \beta 1 \text { treated rat mesangial cell under } \\
\text { high or normal glucose [79] }\end{array}$ & Mesangial cell & $\begin{array}{l}\text { SET7/9个 at promoters of the ECM-associated } \\
\text { genes (ECM } \uparrow)\end{array}$ \\
\hline $\begin{array}{l}\text { High glucose treated mouse } \\
\text { mesangial [81] }\end{array}$ & Mesangial cell & $\begin{array}{l}\text { Suv39h1 } \downarrow, \text { H3K9me3 levels } \downarrow \text { at the promoters of } \\
\text { fibronectin and p21(WAF1) genes (ECM } \uparrow \text { ) }\end{array}$ \\
\hline Type 1 diabetic rat kidney [83] & Mesangial cell & $\mathrm{H} 2 \mathrm{AK} 119 \mathrm{Ub} \downarrow$ and $\mathrm{H} 2 \mathrm{BK} 120 \mathrm{Ub} \downarrow$ (ECM $\uparrow)$ \\
\hline $\begin{array}{l}\text { STZ-induced diabetic rats, TGF- } \beta \text { treated } \\
\text { rat, mouse, and human mesangial } \\
\text { cells [86] }\end{array}$ & Mesangial cell & $\begin{array}{l}\operatorname{miR}-101 \mathrm{~b} \uparrow / \text { Ezh2 } \downarrow \text {, Jmjd3 and Utx } \uparrow / \mathrm{H} 3 \mathrm{~K} 27 \mathrm{me} 3 \downarrow \\
\text { (mesangial dysfunction, ECM } \uparrow \text { ) }\end{array}$ \\
\hline $\begin{array}{l}\text { Kidney tissues from diabetic } d b / d b \text { mice } \\
\text { and patients with DKD, high } \\
\text { glucose-treated mouse podocytes [75] }\end{array}$ & Podocyte & $\begin{array}{l}\text { HDAC9 } \uparrow \text { (oxidative stress, apoptosis, } \\
\text { and inflammation } \uparrow \text { ) }\end{array}$ \\
\hline $\begin{array}{l}\text { Human DKD renal biopsy, STZ-induced } \\
\text { diabetic rats, diabetic } d b / d b \text { mice, glucose, } \\
\text { or AGEs or TGF- } \beta \text { treated podocyte [76] }\end{array}$ & Podocyte & HDAC4 $\uparrow$ (inflammation $\uparrow$ ) \\
\hline $\begin{array}{l}\text { Kidneys of diabetic rats, high glucose } \\
\text { treated podocytes [84] }\end{array}$ & Podocyte & EZH2 expression $\downarrow$ (oxidative stress $\uparrow$ ) \\
\hline $\begin{array}{c}\text { Human FSGS or DKD renal biopsy, } \\
\text { animal studies of adriamycin } \\
\text { nephrotoxicity, subtotal nephrectomy and } \\
\text { diabetic } d b / d b \text { mice, mouse and human } \\
\text { podocytes [85] }\end{array}$ & Podocyte & H3K27me3 $\downarrow$ (podocyte dedifferentiation $\uparrow$ ) \\
\hline $\begin{array}{c}\text { STZ-induced or obese-type }(d b / d b) \\
\text { diabetic mice, high glucose treated } \\
\text { human-derived renal epithelial cells [77] }\end{array}$ & Tubular epithelia & Sirt $1 \downarrow$ (podocyte foot process effacement $\uparrow$ ) \\
\hline $\begin{array}{l}\text { Human DKD renal biopsy compared to } \\
\text { non-DKD minimal change diseases, high } \\
\text { glucose treated human proximal tubular } \\
\text { epithelial cells [82] }\end{array}$ & Tubular epithelia & $\begin{array}{c}\text { SUV39H1个 (DM renal tubules), SUV39H1 } \downarrow \\
\text { (greater glucose and prolonged stimulation in } \\
\text { cells) (inflammation } \uparrow)\end{array}$ \\
\hline $\begin{array}{l}\text { Denote: DCC } \\
\text { Complicatior } \\
\text { disease, AG } \\
\uparrow \text { refers to in }\end{array}$ & $\begin{array}{l}\text { s Control and Cor } \\
\text { plasmic reticulum } \\
\text { ced glycation end } \\
\text { ers to decrease. }\end{array}$ & $\begin{array}{l}\text { ial, EDIC: Epidemiology of Diabetes Interventions and } \\
\text { llular matrix, STZ: Streptozotocin, DKD: Diabetic kidney } \\
\text { FSGS: Focal segmental glomerulosclerosis. Symbols: }\end{array}$ \\
\hline
\end{tabular}




\subsection{Noncoding RNAs in DKD}

Noncoding RNAs including miRNAs and lncRNAs are widely investigated in DKD. Decreased expressions of miR-451 are related to increasing LMP7 and NF- $\mathrm{kB}$ expressions within PBMCs of DKD patients and in high glucose cultured mesangial cells [87]. The suppression of miR-146a induced inflammation in kidneys and macrophages of type 1 diabetic mice [88], while increased ErbB4 and Notch-1 signaling caused podocyte injuries [89]. Overexpression of miR-192 occurred in kidneys of type 1 diabetic mice and TGF- $\beta$-treated mesangial cells, enhancing ECM accumulation and fibrosis through pathways including p53, E-box repressors, and Smad-interacting protein 1 (SIP1) [72,90,91]. On the contrary, decreasing miR-192 in diabetic kidneys and high glucose-treated PT cells correlated with impaired renal function and TGF- $\beta$-induced epithelial-mesenchymal transition (EMT) [92]. MiR-29 family members, including miR-29a, 29b, and 29c, all play an important role in DKD pathogenesis. Downregulated miR-29a enhanced HDAC4 activity to induce nephrin deacetylation, leading to podocyte injury [93]. Lower miR-29b expression restored Sp1 expressions to stimulate TGF- $\beta$ and NF- $\mathrm{kB}$ while increasing collagen matrix production by mesangial cells [94]. MiR-29b was also sponged by Erbb4-IR, an lncRNA, to promote fibrosis in both mesangial and tubular epithelia [95]. Elevation of miR-29c occurred in podocytes and correlated with ECM accumulation via suppressing Sprouty homolog 1 (Spry1) [96]. MiR-34 family members such as miR-34a and 34c were also associated with DKD, since the Notch signaling pathway was activated by decreasing miR-34a or miR-34c, causing podocyte apoptosis [97,98]. In kidneys from type 2 diabetes mice and mouse mesangial cells, decreasing lncRNA 1700020114Rik was linked to the upregulation of miR-34a-5p/Sirt1/HIF-1 $\alpha$ signaling and induced renal fibrosis [99]. Other miRNAs contribute to DKD progression via increasing ECM accumulation or promoting EMT. For example, miR-21, 200b/c, 135a, or 377 promoted ECM accumulation through regulating smad7 [100,101], Akt [102], transient receptor potential cation channel subfamily C member 1 (TRPC1) [103], or fibronectin expression [104]. Loss of miR-26a or let-7b/c/d/g/i altered ECM accumulation via changing CTGF [105], TGF-beta1 receptor 1 (TGFBR1) [106], or Lin28 [107]. Furthermore, downregulation of miR-130b, 200a, or 141 promoted EMT through Snail [108] or smad3 [109] signaling.

LncRNAs can interact with miRNAs to orchestrate their actions on DKD. For example, interactions of 1700020I14Rik-miR-34a-5p and Erbb4-IR-miR-29b are related to DKD, while several lncRNAs complementarily sponge their target siRNAs. During DKD, NR_033515 negatively regulated miR-743b-5p to promote proliferation and EMT of mesangial cells [110]; MALAT1 repressed miR-23c and modulated tubular epithelial pyroptosis [111], and the downregulation of LINC01619 followed by the restoration of miR-27a levels increased ER stress in podocytes [112]. Some lncRNAs are co-transcribed with miRNAs. For instance, lnc-MGC and a megacluster of miRNAs were coordinately expressed to induce mesangial hypertrophy and ECM accumulation in DKD models [113]. PVT1 and miR-1207-5p together contributed to glomerular ECM accumulation under hyperglycemia [114], and MIR503HR co-transcribed with miR-503-5p to exacerbate apoptosis in high glucose-treated tubular epithelia [115]. All in all, many miRNAs and lncRNAs play important roles in the pathogenesis of DKD and work intimately to form intricate regulatory systems. We summarize these findings in Table 3.

Table 3. Noncoding RNAs in diabetic kidney disease.

\begin{tabular}{|c|c|c|}
\hline Study Design (Reference) & Main Cells or Tissue Samples & Epigenetic Changes (Mechanisms Involved) \\
\hline \multicolumn{3}{|c|}{ MicroRNAs } \\
\hline STZ-induced diabetes [88] & Kidney and macrophages of T1D mice & miR-146a $\downarrow$ (inflammation $\uparrow)$ \\
\hline $\begin{array}{c}\text { Glomeruli of early DKD patients, renal cortex of } \\
\text { diabetic (STZ-injected) mice [90] }\end{array}$ & Kidney of T1D mice & $\operatorname{miR}-192 \uparrow(\mathrm{ECM}$, fibrosis $\uparrow)$ \\
\hline $\begin{array}{l}\text { PBMCs of DKD patients, kidneys of } d b / d b \text { mice, } \\
\text { glucose treated mesangial cells [ } 87]\end{array}$ & Mesangial cell & miR-451 $\downarrow$ (inflammation $\uparrow$ ) \\
\hline
\end{tabular}


Table 3. Cont.

\begin{tabular}{|c|c|c|}
\hline Study Design (Reference) & Main Cells or Tissue Samples & Epigenetic Changes (Mechanisms Involved) \\
\hline $\begin{array}{l}\text { STZ-injected diabetic mice, diabetic } d b / d b \text { mice, } \\
\text { TGF- } \beta \text { treated mesangial cells [72] }\end{array}$ & Mesangial cell & $\operatorname{miR}-192 \uparrow(\mathrm{ECM} \uparrow)$ \\
\hline $\begin{array}{l}\text { Glomeruli from diabetic (STZ-injected) mice, } \\
\text { TGF- } \beta \text { treated glomerular mesangial cells [91] }\end{array}$ & Mesangial cell & $\operatorname{miR}-192 \uparrow(\mathrm{ECM} \uparrow)$ \\
\hline $\begin{array}{c}\text { Type } 2 \text { diabetes in } d b / d b \text { mice, cultured mesangial } \\
\text { cell [94] }\end{array}$ & Mesangial cell & $\operatorname{miR}-29 b \downarrow(E C M$, inflammation $\uparrow)$ \\
\hline $\begin{array}{l}\text { Glomeruli of diabetic mice, TGF- } \beta \text { treated mouse } \\
\text { mesangial cells [102] }\end{array}$ & Mesangial cell & miR-200b/c $\uparrow$ (mesangial hypertrophy, ECM $\uparrow$ ) \\
\hline $\begin{array}{l}\text { Serum and kidney tissues of patients with DKD, } \\
d b / d b \text { mice, cultured mesangial cells [103] }\end{array}$ & Mesangial cell & $\operatorname{miR}-135 \mathrm{a} \uparrow(\mathrm{ECM} \uparrow)$ \\
\hline $\begin{array}{l}\text { Mouse diabetic kidney disease models, high } \\
\text { glucose or TGF- } \beta \text { treated human and mouse } \\
\text { mesangial cells [104] }\end{array}$ & Mesangial cell & $\operatorname{miR}-377 \uparrow(E C M \uparrow)$ \\
\hline $\begin{array}{l}\text { Glomeruli of diabetic mice, TGF- } \beta \text {-treated mouse } \\
\text { mesangial cells [107] }\end{array}$ & Mesangial cell & let-7 family members (let-7b/c/d/g/i) $\downarrow(E C M \uparrow)$ \\
\hline $\begin{array}{l}\text { Glomeruli of diabetic patients, glomeruli of } \\
\text { albuminuric BTBR } o b / o b \text { mice [89] }\end{array}$ & Podocyte & miR-146a $\downarrow$ (podocyte injury $\uparrow$ ) \\
\hline $\begin{array}{l}\text { Primary renal glomeruli from STZ-induced } \\
\text { diabetic mice [93] }\end{array}$ & Podocyte & miR-29a $\downarrow$ (podocyte injury $\uparrow$ ) \\
\hline $\begin{array}{l}\text { Glomeruli of } d b / d b \text { mice, kidney microvascular } \\
\text { endothelial cells and podocytes treated with high } \\
\text { glucose [96] }\end{array}$ & Podocyte & $\operatorname{miR}-29 \mathrm{c} \uparrow(\mathrm{ECM} \uparrow)$ \\
\hline High glucose treated mouse podocyte [97] & Podocyte & miR-34a $\downarrow$ (podocyte apoptosis $\uparrow$ ) \\
\hline High glucose treated podocytes [98] & Podocyte & miR-34c $\downarrow$ (podocyte apoptosis $\uparrow$ ) \\
\hline $\begin{array}{l}\text { Humans and mouse (STZ-injected) models of } \\
\text { DKD, cultured podocytes [105] }\end{array}$ & Podocyte & $\operatorname{miR}-26 \mathrm{a} \downarrow(\mathrm{ECM} \uparrow)$ \\
\hline $\begin{array}{c}\text { Renal biopsy from patients with diabetic kidney } \\
\text { disease, high glucose treated proximal tubular } \\
\text { cells [92] }\end{array}$ & Tubular epithelia & $\operatorname{miR}-192 \downarrow($ EMT $\uparrow)$ \\
\hline $\begin{array}{l}\text { Diabetic kidney disease animal models, cultured } \\
\text { human tubular epithelial cells [100] }\end{array}$ & Tubular epithelia & $\operatorname{miR}-21 \uparrow(\mathrm{ECM} \uparrow)$ \\
\hline $\begin{array}{l}\text { Human DKD, models of fibrotic renal disease and } \\
\text { experimental DKD [101] }\end{array}$ & Tubular epithelia & $\operatorname{miR}-21 \uparrow(\mathrm{ECM} \uparrow)$ \\
\hline $\begin{array}{l}\text { Mouse models of early and advanced DKD, } \\
\text { TGF- } \beta 1 \text { treated rat tubular cells [106] }\end{array}$ & Tubular epithelia & let-7b $\downarrow(E C M \uparrow)$ \\
\hline $\begin{array}{l}\text { Renal biopsies and plasma of DKD patients, } \\
\text { STZ-induced diabetic rats, high glucose cultured } \\
\text { rat proximal tubular cells [108] }\end{array}$ & Tubular epithelia & $\operatorname{miR}-130 b \downarrow(E M T \uparrow)$ \\
\hline $\begin{array}{l}\text { Early and advanced DKD mice models, TGF- } \beta \\
\text { treated rat proximal-tubular cells [109] }\end{array}$ & Tubular epithelia & miR-141 and miR-200a $\downarrow$ (EMT $\uparrow)$ \\
\hline \multicolumn{3}{|c|}{ Long noncoding RNAs } \\
\hline $\begin{array}{l}\text { Renal tissues of } d b / d b \text { DKD mice, mouse mesangial } \\
\text { cell [99] }\end{array}$ & Mesangial cell & 1700020I14Rik $\downarrow$, miR-34a-5p $\uparrow($ fibrosis $\uparrow)$ \\
\hline $\begin{array}{l}\text { Serum of DKD patients, mouse mesangial } \\
\text { cells [110] }\end{array}$ & Mesangial cell & NR_033515个, miR-743b-5p $\downarrow$ (EMT $\uparrow)$ \\
\hline $\begin{array}{l}\text { Glomeruli of DKD mouse models, TGF-beta or } \\
\text { high glucose treated mesangial cells [113] }\end{array}$ & Mesangial cell & $\begin{array}{c}\operatorname{lnc}-\mathrm{MGC} \uparrow \text {, a megacluster of microRNAs } \uparrow \\
\text { (ER stress } \uparrow \text { ) }\end{array}$ \\
\hline $\begin{array}{l}d b / d b \text { mice, mouse mesangial cells and tubular } \\
\text { epithelial cells [95] }\end{array}$ & Mesangial cell and tubular epithelia & Erbb4-IR $\uparrow, \operatorname{miR}-29 \mathrm{~b} \downarrow$ (fibrosis $\uparrow)$ \\
\hline $\begin{array}{l}\text { Mesangial cells and human proximal tubular } \\
\text { cells [114] }\end{array}$ & Mesangial cell and tubular epithelia & PVT1 $\uparrow$ miR-1207-5p $\uparrow(E C M \uparrow)$ \\
\hline
\end{tabular}


Table 3. Cont.

\begin{tabular}{|c|c|c|}
\hline Study Design (Reference) & Main Cells or Tissue Samples & Epigenetic Changes (Mechanisms Involved) \\
\hline $\begin{array}{l}\text { Human DKD renal biopsy, diabetic rat, high } \\
\text { glucose cultured podocyte [112] }\end{array}$ & Podocyte & LINC01619 $\downarrow$, miR-27a $\uparrow($ ER stress $\uparrow)$ \\
\hline $\begin{array}{l}\text { STZ-induced diabetic rats, high glucose treated } \\
\text { renal tubular epithelial cell [111] }\end{array}$ & Tubular epithelia & MALAT1 $\uparrow$, miR-23c $\downarrow$ (inflammation $\uparrow$ ) \\
\hline $\begin{array}{l}\text { High glucose treated human proximal tubular } \\
\text { cells [115] }\end{array}$ & Tubular epithelia & 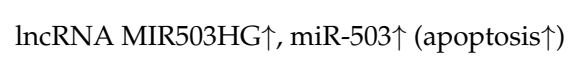 \\
\hline
\end{tabular}

Denote: STZ: Streptozotocin, T1D: Type 1 diabetic, DKD: Diabetic kidney disease, ECM: Extracellular matrix PBMCs: Peripheral blood mononuclear cells, EMT: Epithelial-to-mesenchymal transition, and ER: Endoplasmic reticulum. Symbols: $\uparrow$ refers to increase; $\downarrow$ refers to decrease.

\section{Kidney Cell-Centric View of Epigenetic Modifications}

We further summarize regulatory actions exerted by three major epigenetic mechanisms on DKD. Studies using samples from patients with CKD or animal models of CKD without focusing on a specific type of CKD are not included here. To concisely depict the diverse epigenetic regulations from a cell-centric view, we schematically constructed diagrams to describe epigenetic modifications associated with mesangial cells (Figure 2), podocytes (Figure 3), and tubular epithelia (Figure 4). However, experimental studies measuring epigenetic marks from whole kidney samples without addressing specific kidney cells are not detailed in figures due to the lack of relevant evidence. A future approach may be able to leverage our summary results for devising target therapy for ameliorating DKD progression.

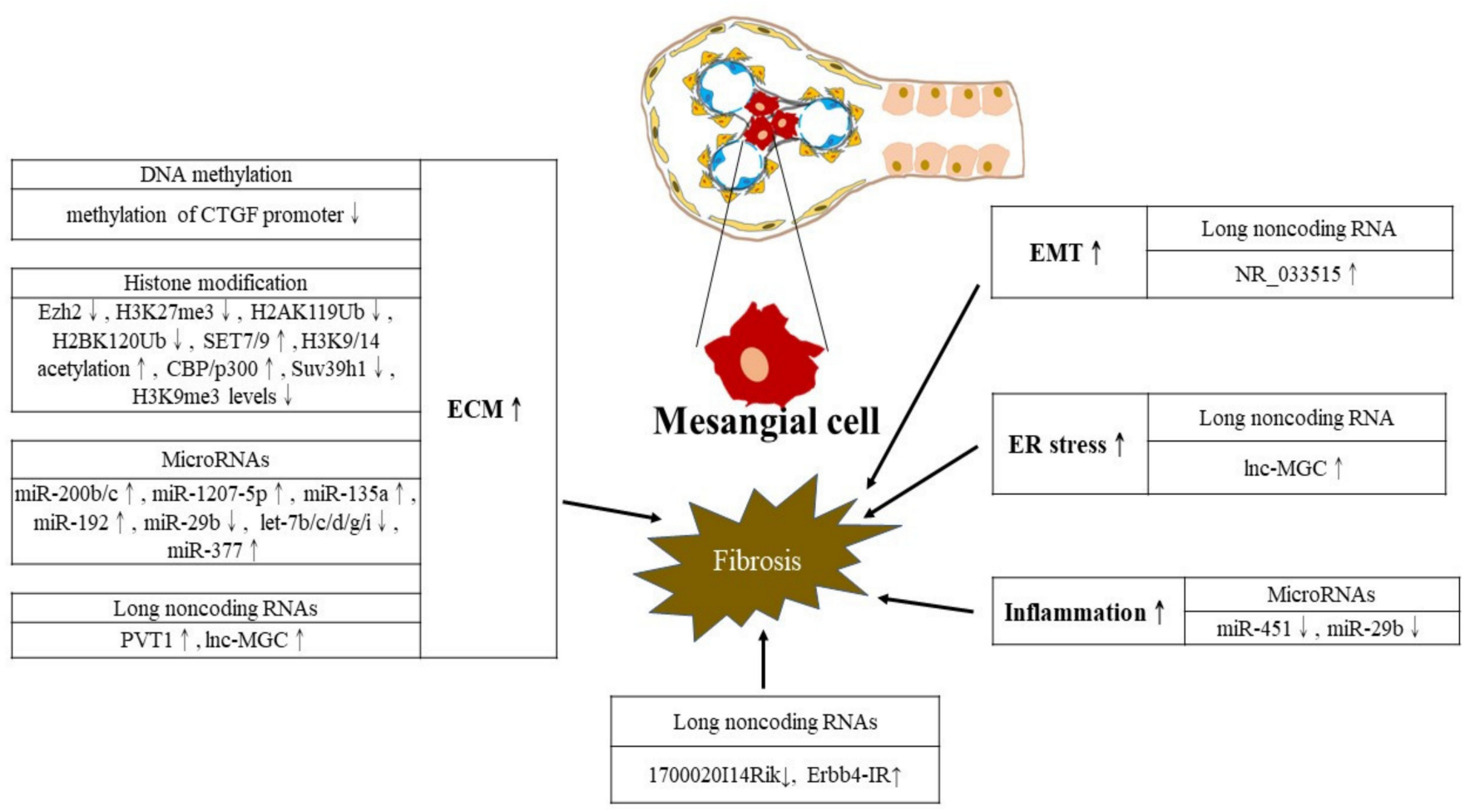

\section{Mesangial cell associated epigenetic regulation in diabetic kidney disease}

Figure 2. Mesangial cell associated epigenetic regulation in DKD. Denote: ECM: Extracellular matrix, EMT: Epithelial-to-mesenchymal transition, and ER: Endoplasmic reticulum. Symbols: $\uparrow$ refers to increase; $\downarrow$ refers to decrease. 


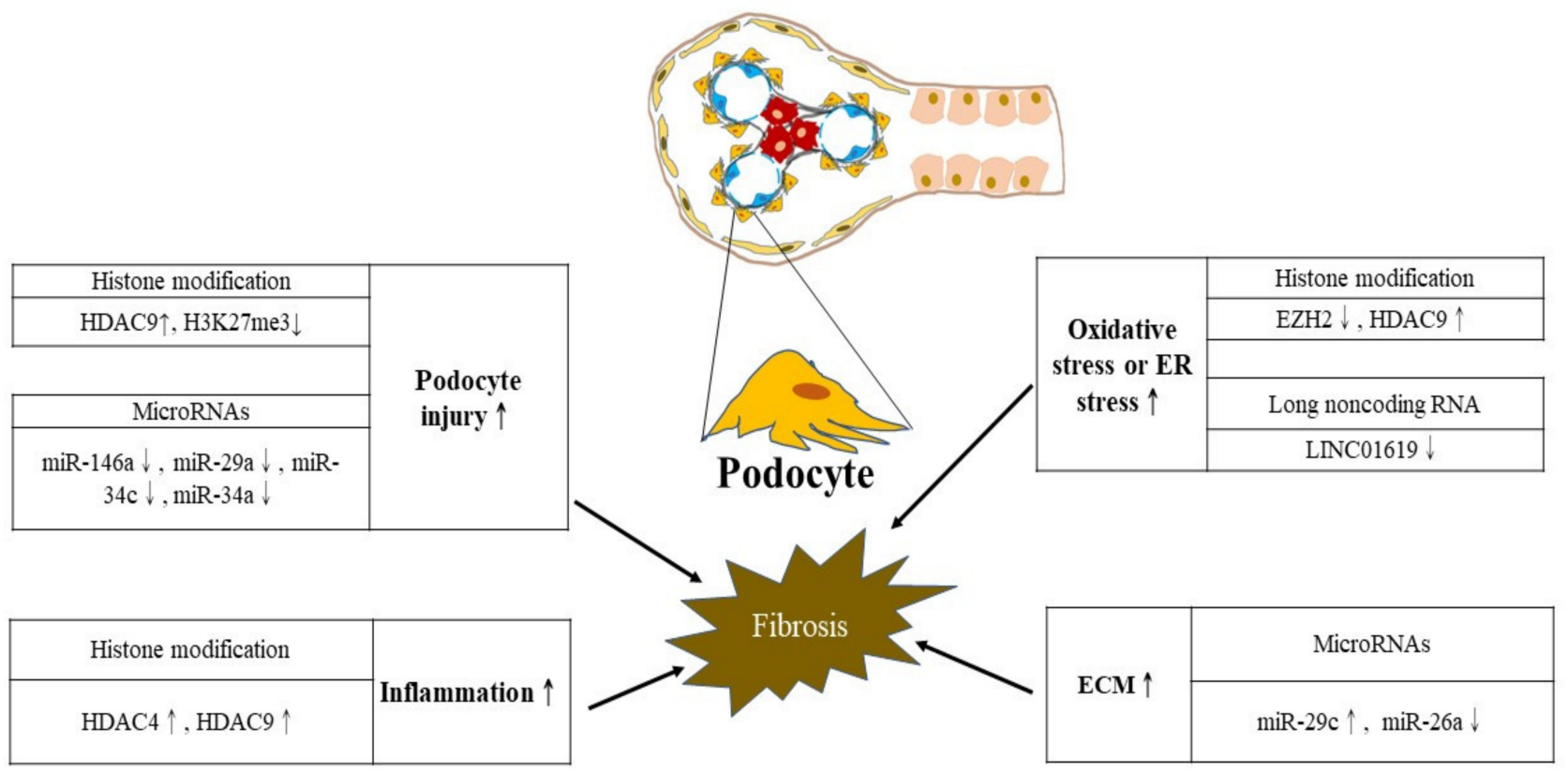

Podocyte associated epigenetic regulation in diabetic kidney disease

Figure 3. Podocyte-associated epigenetic regulation in DKD. Denote: ECM: Extracellular matrix and ER: Endoplasmic reticulum. Symbols: $\uparrow$ refers to increase; $\downarrow$ refers to decrease.

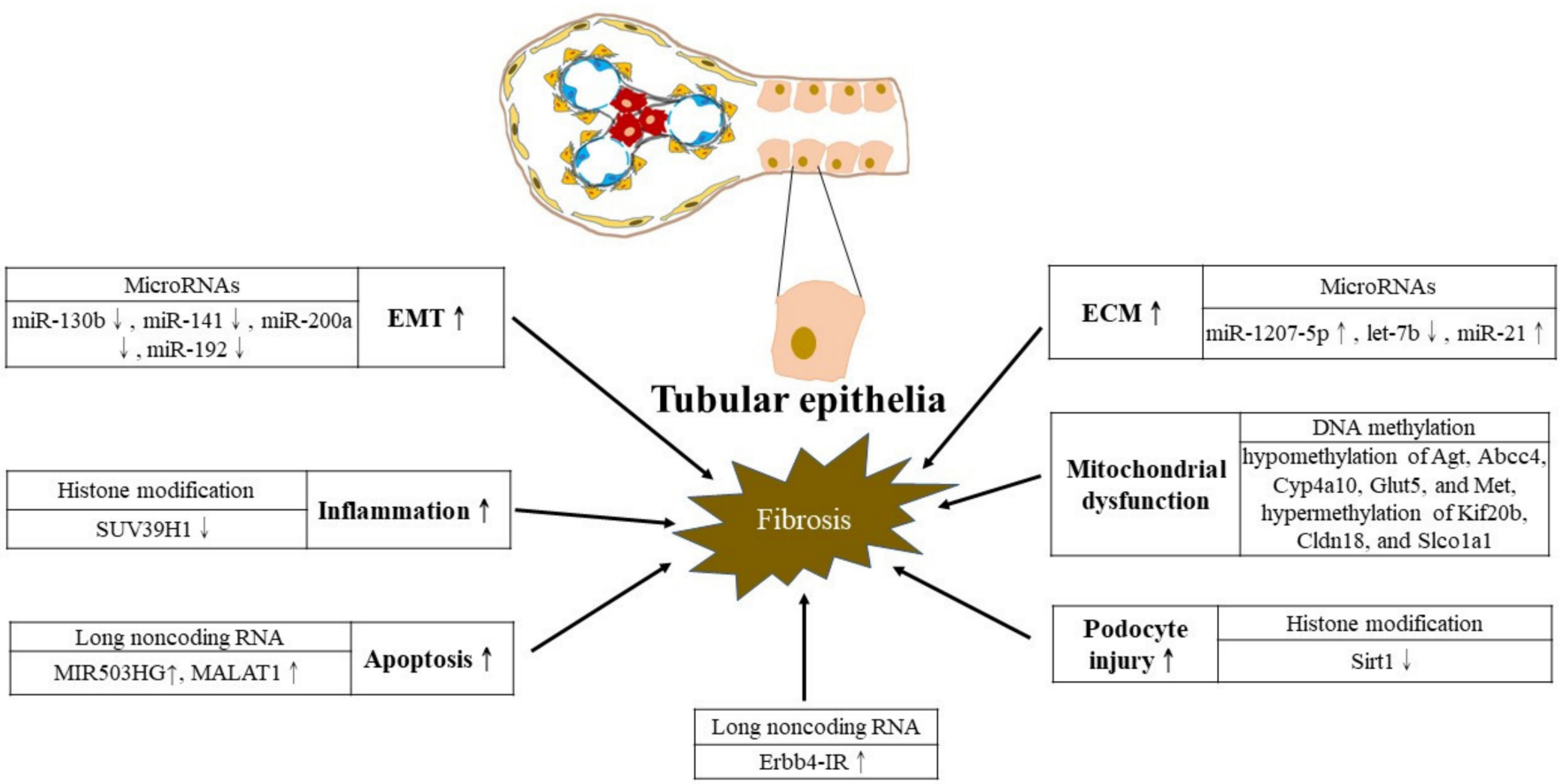

Tubular epithelia associated epigenetic regulation in diabetic kidney disease

Figure 4. Tubular epithelia-associated epigenetic regulation in DKD. Denote: ECM: Extracellular matrix and EMT: Epithelial-to-mesenchymal transition. Symbols: $\uparrow$ refers to increase; $\downarrow$ refers to decrease. 


\section{Epigenetic Modifications of Glomerular Endothelial Cells in DKD}

DKD is a microvascular complication of diabetes, and several studies found that hyperglycemia-mediated epigenetic alternations promoted glomerular endothelial dysfunction. For example, the endothelial nitric oxide synthase (eNOS), a major enzyme in renal vasculature, has been shown to be regulated by histone modification [116]. The decreased NO production largely contributes to the endothelial dysfunction observed in DKD [117]. Indeed, using eNOS knockout diabetic mice as an animal model of advanced DKD for comparison with models with mild DKD and WT diabetes, Fu et al. disclosed that the differentially expressed genes in isolated glomerular endothelial cells were enriched functionally for angiogenesis and epigenetic regulation [118]. Another study investigating the role of long non-coding RNA metastasis-associated lung adenocarcinoma transcript 1 (MALAT1) in high glucose-induced glomerular endothelial dysfunction also showed that MALAT1 could epigenetically inhibit klotho transcription via recruiting methyltransferase G9a to increase H3K9me1 occupancy on the klotho promoter [119]. Moreover, culturing glomerular endothelial cells with conditional media from high glucose-treated podocytes could increase the phosphorylation of histone $\mathrm{H} 3$ serine 10 at the vascular cell adhesion molecule 1 (VCAM1) promoter, with increased protein productions [120]. These findings suggest that cells within glomeruli may interact with each other and contribute to DKD pathogenesis.

\section{Epigenetic Biomarkers}

Epigenetic markers, such as microRNAs, can be detected in the circulation and urine. Multiple studies have examined miRNA levels in patients' blood and urine, aiming to identify useful biomarkers for early diagnosis and assessment of disease activity in DKD. The elevation of miR-192, 194, and 215 in urinary exosomes was considered as a biomarker for patients with type $2 \mathrm{DM}$ and early DKD [121]. In patients with type $1 \mathrm{DM}$ and incipient DKD, urinary exosomal miR-130a and 145 increased significantly while miR-155 and 424 drastically decreased [122]. In DKD, the reduction in circulating miR-126 was negatively correlated with albuminuria [123] and a higher risk for DM-related micro- and macro-complications [124], whereas the downregulation of urinary miR-2861, 1915-3p, and 4532 was associated with impaired renal function [125]. We summarize these findings in Table 4.

Table 4. Epigenetic biomarkers and agents to modulate epigenetics in diabetic kidney disease.

\begin{tabular}{|c|c|c|}
\hline \multicolumn{3}{|c|}{ Epigenetic Biomarkers } \\
\hline Status of DKD (Reference) & Samples & Epigenetic Biomarkers \\
\hline DKD [118] & Whole blood & 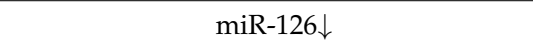 \\
\hline $\begin{array}{l}\text { DM with micro-/macrovascular } \\
\text { complication [119] }\end{array}$ & Serum & 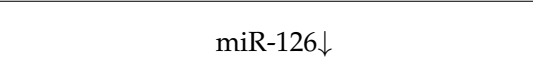 \\
\hline DM with microalbuminuria [116] & Urinary exosome & $\operatorname{miR}-192 \uparrow, \operatorname{miR}-194 \uparrow$, and $\operatorname{miR}-215 \uparrow$ \\
\hline $\begin{array}{l}\text { Type } 1 \text { DM with incipient diabetic kidney } \\
\text { disease [117] }\end{array}$ & Urinary exosome & 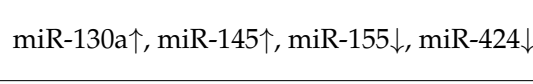 \\
\hline DKD [120] & Urine & miR-2861 $\downarrow$, miR-1915-3p $\downarrow$, miR-4532 $\downarrow$ \\
\hline \multicolumn{3}{|c|}{ Agents to Modulate Epigenetics } \\
\hline Types of Nephropathy (Reference) & Agents to Modulate Epigenetics & Epigenetic Effects \\
\hline DKD [122] & 5-azacytidine or 5-aza-2'-deoxycytidine & DNA demethylation \\
\hline DKD or CKD [67] & BMP7 & $\begin{array}{l}\text { Tet3 } \uparrow \text { and normalization of Rasal1 } \\
\text { promoter hypermethylation }\end{array}$ \\
\hline DKD [78] & Apelin-13 & Histone deacetylation \\
\hline DKD [123] & MS417 & Bromodomain inhibitor \\
\hline
\end{tabular}

Denote: DKD: Diabetic kidney disease, DM: Diabetes mellitus, and CKD: Chronic kidney disease. Symbols: $\uparrow$ refers to increase; $\downarrow$ refers to decrease. 


\section{Epigenetic Machineries for Therapeutic Applications}

Epigenome-targeting drugs including DNA methylation inhibitors, histone modifiers, and bromodomain inhibitors have been approved for clinical use or tested in oncology trials [126]. These drugs are also potential candidates for treating other diseases with epigenetic dysregulation, such as DKD. Indeed, as shown in Table 4, DNA demethylating agents (5-azacytidine or 5-aza-2'-deoxycytidine) attenuate diabetes-related podocyte injuries in animal models [127]. Bone morphogenic protein 7 (BMP7) administration can increase Tet3 expression and reverse the Rasal1 promoter hypermethylation with the amelioration of renal fibrosis in UUO and DKD animal models [67]. The adipokine apelin-13 has been shown to attenuate DKD progression by inducing histone deacetylation [78]. Moreover, MS417 as a bromodomain and extraterminal (BET)-specific bromodomain inhibitor can attenuate proteinuria in DKD via blocking acetylation-mediated association of p65 and STAT3 with BET proteins [128].

Although DNA demethylation agents and histone modifiers show great promise for treating DKD, their broad and non-specific long-term effects are still of concern. Recently, the CRISPR-Cas9 system has been developed to perform site-specific epigenetic modifications $[129,130]$. Applying this technology to precisely and timely edit epigenetic elements may broaden the therapeutic armamentarium against DKD.

\section{Conclusions}

Multifactorial interventions to control hyperglycemia, hypertension, and dyslipidemia remain fundamental for ameliorating late complications in patients with $\mathrm{DKD}$, and this approach has been proven in long-term multicenter randomized control trials [131]. Moreover, cardiovascular outcome trials of sodium-glucose co-transporter 2 inhibitors (SGLT2i) have been reported to beneficially influence cardiovascular and renal outcomes in patients with type 2 DM [132]. Therefore, a multifactorial approach, in addition to the use of nephroprotective agents, serves as a practical strategy for managing DKD. Epigenetic machineries undoubtedly play an active role in steering the initiation and progression of DKD. Our current understandings of the epigenetic dynamics during DKD progression remain fragmented. The interactions between different epigenetic processes enrich the complexity. Nonetheless, the increased availability of multi-omic approaches will provide us with more insight into epigenomic pathology in DKD. With the rising applicability of epigenome-directed editing technology, epigenetic therapies will likely be applicable in the future as a safe and effective way to treat DKD.

Author Contributions: Writing-original draft preparation, F.-C.K.; writing-review and editing, C.-T.C.; supervision, S.-H.L. All authors have read and agreed to the published version of the manuscript.

Funding: This research received no external funding.

Institutional Review Board Statement: Not applicable.

Informed Consent Statement: Not applicable.

Conflicts of Interest: The authors declare no conflict of interest.

\section{References}

1. GBD 2017 DALYs and HALE Collaborators. Global, Regional, and National Disability-Adjusted Life-Years (DALYs) for 359 Diseases and Injuries and Healthy Life Expectancy (HALE) for 195 Countries and Territories, 1990-2017: A Systematic Analysis for the Global Burden of Disease Study 2017. Lancet 2018, 392, 1859-1922. [CrossRef]

2. Wang, V.; Vilme, H.; Maciejewski, M.L.; Boulware, L.E. The Economic Burden of Chronic Kidney Disease and End-Stage Renal Disease. Semin. Nephrol. 2016, 36, 319-330. [CrossRef] [PubMed]

3. Hill, N.R.; Fatoba, S.T.; Oke, J.L.; Hirst, J.A.; O'Callaghan, C.A.; Lasserson, D.S.; Hobbs, F.D.R. Data from: Global prevalence of chronic kidney disease: A systematic review and meta-analysis. PLoS ONE 2016, 11, e0158765. [CrossRef] [PubMed]

4. Fioretto, P.; Mauer, M. Histopathology of Diabetic Nephropathy. Semin. Nephrol. 2007, 27, 195-207. [CrossRef] [PubMed]

5. Yan, M.-T.; Chao, C.-T.; Lin, S.-H. Chronic Kidney Disease: Strategies to Retard Progression. Int. J. Mol. Sci. 2021, $22,10084$. [CrossRef]

6. Gu, H.F. Genetic and Epigenetic Studies in Diabetic Kidney Disease. Front. Genet. 2019, 10, 507. [CrossRef] 
7. Tin, A.; Köttgen, A. Genome-Wide Association Studies of CKD and Related Traits. Clin. J. Am. Soc. Nephrol. 2020, 15, $1643-1656$. [CrossRef]

8. Wuttke, M.; Li, Y.; Li, M.; Sieber, K.B.; Feitosa, M.F.; Gorski, M.; Tin, A.; Wang, L.; Chu, A.Y.; Hoppmann, A.; et al. A catalog of genetic loci associated with kidney function from analyses of a million individuals. Nat. Genet. 2019, 51, 957-972. [CrossRef]

9. Teumer, A.; Li, Y.; Ghasemi, S.; Prins, B.P.; Wuttke, M.; Hermle, T.; Giri, A.; Sieber, K.B.; Qiu, C.; Kirsten, H.; et al. Genomewide association meta-analyses and fine-mapping elucidate pathways influencing albuminuria. Nat. Commun. 2019, 10, 1-19. [CrossRef]

10. Kato, M.; Natarajan, R. Epigenetics and epigenomics in diabetic kidney disease and metabolic memory. Nat. Rev. Nephrol. 2019, 15, 327-345. [CrossRef]

11. Smyth, L.J.; McKay, G.J.; Maxwell, A.P.; McKnight, A.J. DNA hypermethylation and DNA hypomethylation is present at different loci in chronic kidney disease. Epigenetics 2013, 9, 366-376. [CrossRef] [PubMed]

12. Pang, T.Y.C.; Short, A.K.; Bredy, T.W.; Hannan, A.J. Transgenerational paternal transmission of acquired traits: Stress-induced modification of the sperm regulatory transcriptome and offspring phenotypes. Curr. Opin. Behav. Sci. 2017, 14, 140-147. [CrossRef] [PubMed]

13. Van Otterdijk, S.D.; Michels, K.B. Transgenerational epigenetic inheritance in mammals: How good is the evidence? FASEB J 2016, 30, 2457-2465. [CrossRef] [PubMed]

14. Majchrzak-Celińska, A.; Warych, A.; Szoszkiewicz, M. Novel Approaches to Epigenetic Therapies: From Drug Combinations to Epigenetic Editing. Genes 2021, 12, 208. [CrossRef]

15. Leone, G.; D'Alo, F.; Zardo, G.; Voso, M.T.; Nervi, C. Epigenetic Treatment of Myelodysplastic Syndromes and Acute Myeloid Leukemias. Curr. Med. Chem. 2008, 15, 1274-1287. [CrossRef]

16. Ehrlich, M.; Gama-Sosa, M.A.; Huang, L.-H.; Midgett, R.M.; Kuo, K.C.; McCune, R.A.; Gehrke, C. Amount and distribution of 5-methylcytosine in human DNA from different types of tissues or cells. Nucleic Acids Res. 1982, 10, 2709-2721. [CrossRef]

17. Deaton, A.M.; Bird, A. CpG islands and the regulation of transcription. Genes Dev. 2011, 25, 1010-1022. [CrossRef]

18. Saxonov, S.; Berg, P.; Brutlag, D.L. A genome-wide analysis of CpG dinucleotides in the human genome distinguishes two distinct classes of promoters. Proc. Natl. Acad. Sci. USA 2006, 103, 1412-1417. [CrossRef]

19. Bird, A. DNA methylation patterns and epigenetic memory. Genes Dev. 2002, 16, 6-21. [CrossRef]

20. Hermann, A.; Goyal, R.; Jeltsch, A. The Dnmt1 DNA-(cytosine-C5)-methyltransferase Methylates DNA Processively with High Preference for Hemimethylated Target Sites. J. Biol. Chem. 2004, 279, 48350-48359. [CrossRef]

21. Pradhan, S.; Bacolla, A.; Wells, R.D.; Roberts, R.J. Recombinant Human DNA (Cytosine-5) Methyltransferase: I. Expression, purification, and comparison of de novo and maintenance methylation. J. Biol. Chem. 1999, 274, 33002-33010. [CrossRef] [PubMed]

22. Bestor, T.H. Activation of mammalian DNA methyltransferase by cleavage of a Zn binding regulatory domain. EMBO J. 1992, 11 , 2611-2617. [CrossRef] [PubMed]

23. Okano, M.; Bell, D.W.; Haber, D.A.; Li, E. DNA methyltransferases Dnmt3a and Dnmt3b are essential for de novo methylation and mammalian development. Cell 1999, 99, 247-257. [CrossRef]

24. Hsieh, C.-L. In Vivo Activity of Murine De Novo Methyltransferases, Dnmt3a and Dnmt3b. Mol. Cell. Biol. 1999, 19, 8211-8218. [CrossRef]

25. Okano, M.; Xie, S.; Li, E. Cloning and characterization of a family of novel mammalian DNA (cytosine-5) methyltransferases. Nat. Genet. 1998, 19, 219-220. [CrossRef]

26. Tahiliani, M.; Koh, K.P.; Shen, Y.; Pastor, W.A.; Bandukwala, H.; Brudno, Y.; Agarwal, S.; Iyer, L.M.; Liu, D.R.; Aravind, L.; et al. Conversion of 5-Methylcytosine to 5-Hydroxymethylcytosine in Mammalian DNA by MLL Partner TET1. Science 2009, 324, 930-935. [CrossRef]

27. Hamidi, T.; Singh, A.K.; Chen, T. Genetic alterations of DNA methylation machinery in human diseases. Epigenomics 2015, 7, 247-265. [CrossRef]

28. Mariño-Ramírez, L.; Kann, M.G.; Shoemaker, B.A.; Landsman, D. Histone structure and nucleosome stability. Expert Rev. Proteom. 2005, 2, 719-729. [CrossRef]

29. Luger, K.; Mäder, A.W.; Richmond, R.K.; Sargent, D.F.; Richmond, T.J. Crystal structure of the nucleosome core particle at $2.8 \AA$ resolution. Nature 1997, 389, 251-260. [CrossRef]

30. Song, N.; Liu, J.; An, S.; Nishino, T.; Hishikawa, Y.; Koji, T. Immunohistochemical Analysis of Histone H3 Modifications in Germ Cells during Mouse Spermatogenesis. Acta Histochem. Cytochem. 2011, 44, 183-190. [CrossRef] [PubMed]

31. Jenuwein, T.; Allis, C.D. Translating the Histone Code. Science 2001, 293, 1074-1080. [CrossRef]

32. Zhou, V.W.; Goren, A.; Bernstein, B.E. Charting histone modifications and the functional organization of mammalian genomes. Nat. Rev. Genet. 2011, 12, 7-18. [CrossRef]

33. Kouzarides, T. Chromatin modifications and their function. Cell 2007, 128, 693-705. [CrossRef]

34. Yu, C.; Zhuang, S. Histone Methyltransferases as Therapeutic Targets for Kidney Diseases. Front. Pharmacol. $2019,10,1393$. [CrossRef] [PubMed]

35. Li, B.; Carey, M.; Workman, J.L. The Role of Chromatin during Transcription. Cell 2007, 128, 707-719. [CrossRef] [PubMed]

36. Sims, R.J., III; Nishioka, K.; Reinberg, D. Histone lysine methylation: A signature for chromatin function. Trends Genet. 2003, 19, 629-639. [CrossRef] 
37. Filippakopoulos, P.; Knapp, S. Targeting bromodomains: Epigenetic readers of lysine acetylation. Nat. Rev. Drug Discov. 2014, 13, 337-356. [CrossRef] [PubMed]

38. Bartel, D.P. MicroRNAs: Target Recognition and Regulatory Functions. Cell 2009, 136, 215-233. [CrossRef]

39. Laganà, A.; Veneziano, D.; Russo, F.; Pulvirenti, A.; Giugno, R.; Croce, C.M.; Ferro, A. Computational Design of Artificial RNA Molecules for Gene Regulation. Methods Mol. Biol. 2015, 1269, 393-412. [PubMed]

40. Siomi, M.C.; Sato, K.; Pezic, D.; Aravin, A.A. PIWI-interacting small RNAs: The vanguard of genome defence. Nat. Rev. Mol. Cell Biol. 2011, 12, 246-258. [CrossRef]

41. Dorner, S.; Eulalio, A.; Huntzinger, E.; Izaurralde, E. Delving into the diversity of silencing pathways. In EMBO Reports 2007, Proceedings of the Symposium on MicroRNAs and siRNAs: Biological Functions and Mechanisms, Keystone, CO, USA, 28 January and 2 February 2007; European Molecular Biology Organization: Corvallis, OR, USA, 2017; Volume 8, pp. 723-729.

42. Statello, L.; Guo, C.-J.; Chen, L.-L.; Huarte, M. Gene regulation by long non-coding RNAs and its biological functions. Nat. Rev. Mol. Cell Biol. 2021, 22, 96-118. [CrossRef] [PubMed]

43. Hsu, C.-C.; Tu, S.-T.; Sheu, W.H.-H. 2019 Diabetes Atlas: Achievements and challenges in diabetes care in Taiwan. J. Formos. Med. Assoc. 2019, 118, S130-S134. [CrossRef] [PubMed]

44. Zhang, X.-X.; Kong, J.; Yun, K. Prevalence of Diabetic Nephropathy among Patients with Type 2 Diabetes Mellitus in China: A Meta-Analysis of Observational Studies. J. Diabetes Res. 2020, 2020, 2315607. [CrossRef]

45. Vasishta, S.; Umakanth, S.; Adiga, P.; Joshi, M.B. Extrinsic and intrinsic factors influencing metabolic memory in type 2 dia-betes. Vasc. Pharm. 2022, 142, 106933. [CrossRef] [PubMed]

46. Bell, C.G.; Teschendorff, A.E.; Rakyan, V.K.; Maxwell, A.P.; Beck, S.; Savage, D.A. Genome-wide DNA methylation analysis for diabetic nephropathy in type 1 diabetes mellitus. BMC Med. Genom. 2010, 3, 33. [CrossRef]

47. Swan, E.J.; Maxwell, A.P.; McKnight, A.J. Distinct methylation patterns in genes that affect mitochondrial function are associated with kidney disease in blood-derived DNA from individuals with Type 1 diabetes. Diabet. Med. 2015, 32, 1110-1115. [CrossRef]

48. Chen, Z.; Miao, F.; Paterson, A.D.; Lachin, J.M.; Zhang, L.; Schones, D.E.; Wu, X.; Wang, J.; Tompkins, J.D.; Genuth, S.; et al Epigenomic profiling reveals an association between persistence of DNA methylation and metabolic memory in the DCCT/EDIC type 1 diabetes cohort. Proc. Natl. Acad. Sci. USA 2016, 113, E3002-E3011. [CrossRef]

49. Alhawiti, N.M.; Al Mahri, S.; Aziz, M.A.; Malik, S.S.; Mohammad, S. TXNIP in Metabolic Regulation: Physiological Role and Therapeutic Outlook. Curr. Drug Targets 2017, 18, 1095-1103. [CrossRef]

50. VanderJagt, T.A.; Neugebauer, M.H.; Morgan, M.; Bowden, D.W.; Shah, V.O. Epigenetic profiles of pre-diabetes transitioning to type 2 diabetes and nephropathy. World J. Diabetes 2015, 6, 1113-1121. [CrossRef]

51. Sheng, X.; Qiu, C.; Liu, H.; Gluck, C.; Hsu, J.Y.; He, J.; Hsu, C.-Y.; Sha, D.; Weir, M.R.; Isakova, T.; et al. Systematic integrated analysis of genetic and epigenetic variation in diabetic kidney disease. Proc. Natl. Acad. Sci. USA 2020, 117, 29013-29024. [CrossRef]

52. Chu, A.Y.; Tin, A.; Schlosser, P.; Ko, Y.-A.; Qiu, C.; Yao, C.; Joehanes, R.; Grams, M.E.; Liang, L.; Gluck, C.A.; et al. Epigenome-wide association studies identify DNA methylation associated with kidney function. Nat. Commun. 2017, 8, 1286. [CrossRef]

53. Marumo, T.; Yagi, S.; Kawarazaki, W.; Nishimoto, M.; Ayuzawa, N.; Watanabe, A.; Ueda, K.; Hirahashi, J.; Hishikawa, K.; Sakurai, H.; et al. Diabetes Induces Aberrant DNA Methylation in the Proximal Tubules of the Kidney. J. Am. Soc. Nephrol. 2015, 26, 2388-2397. [CrossRef]

54. Chen, G.; Chen, H.; Ren, S.; Xia, M.; Zhu, J.; Liu, Y.; Zhang, L.; Tang, L.; Sun, L.; Liu, H.; et al. Aberrant DNA methylation of mTOR pathway genes promotes inflammatory activation of immune cells in diabetic kidney disease. Kidney Int. 2019, 96, 409-420. [CrossRef]

55. Peng, R.; Liu, H.; Peng, H.; Zhou, J.; Zha, H.; Chen, X.; Zhang, L.; Sun, Y.; Yin, P.; Wen, L.; et al. Promoter hypermethylation of let-7a-3 is relevant to its down-expression in diabetic nephropathy by targeting UHRF1. Gene 2015, 570, 57-63. [CrossRef]

56. Liu, X.; Gao, Q.; Li, P.; Zhao, Q.; Zhang, J.; Li, J.; Koseki, H.; Wong, J. UHRF1 targets DNMT1 for DNA methylation through cooperative binding of hemi-methylated DNA and methylated H3K9. Nat. Commun. 2013, 4, 1563. [CrossRef]

57. Zhu, Y.; Wang, X.; Zhou, X.; Ding, L.; Liu, D.; Xu, H. DNMT1-mediated PPAR $\alpha$ methylation aggravates damage of retinal tissues in diabetic retinopathy mice. Biol. Res. 2021, 54, 25. [CrossRef] [PubMed]

58. Aso, Y.; Yoshida, N.; Okumura, K.I.; Wakabayashi, S.; Matsutomo, R.; Takebayashi, K.; Inukai, T. Coagulation and inflammation in overt diabetic nephropathy: Association with hyperhomocysteinemia. Clin. Chim. Acta 2004, 348, 139-145. [CrossRef]

59. Sayanthooran, S.; Magana-Arachchi, D.N.; Gunerathne, L.; Abeysekara, T. Potential diagnostic biomarkers for chronic kidney disease of unknown etiology (CKDu) in Sri Lanka: A pilot study. BMC Nephrol. 2017, 18, 31. [CrossRef] [PubMed]

60. Aldemir, O.; Turgut, F.; Gokce, C. The association between methylation levels of targeted genes and albuminuria in patients with early diabetic kidney disease. Ren. Fail. 2017, 39, 597-601. [CrossRef] [PubMed]

61. Yang, X.-H.; Cao, R.-F.; Yu, Y.; Sui, M.; Zhang, T.; Xu, J.-Y.; Wang, X.-M. A study on the correlation between MTHFR promoter methylation and diabetic nephropathy. Am. J. Transl. Res. 2016, 8, 4960-4967.

62. Gu, T.; Falhammar, H.; Gu, H.F.; Brismar, K. Epigenetic analyses of the insulin-like growth factor binding protein 1 gene in type 1 diabetes and diabetic nephropathy. Clin. Epigenetics 2014, 6, 10. [CrossRef]

63. Yokoi, H.; Mukoyama, M.; Mori, K.; Kasahara, M.; Suganami, T.; Sawai, K.; Yoshioka, T.; Saito, Y.; Ogawa, Y.; Kuwabara, T.; et al. Overexpression of connective tissue growth factor in podocytes worsens diabetic nephropathy in mice. Kidney Int. 2008, 73, 446-455. [CrossRef] 
64. Zhang, H.; Cai, X.; Yi, B.; Huang, J.; Wang, J.; Sun, J. Correlation of CTGF gene promoter methylation with CTGF expression in type 2 diabetes mellitus with or without nephropathy. Mol. Med. Rep. 2014, 9, 2138-2144. [CrossRef]

65. Yi, B.; Zhang, H.; Zhou, H.; Cai, X.; Sun, J.; Liu, Y. High glucose induce the demethylation of CTGF promoter and gene ex-pression. Chin. J. Cell. Mol. Immunol. 2011, 27, 747-750.

66. Bechtel, W.; McGoohan, S.; Zeisberg, E.M.; Müller, G.A.; Kalbacher, H.; Salant, D.J.; Müller, C.A.; Kalluri, R.; Zeisberg, M. Methylation determines fibroblast activation and fibrogenesis in the kidney. Nat. Med. 2010, 16, 544-550. [CrossRef] [PubMed]

67. Tampe, B.; Tampe, D.; Müller, C.A.; Sugimoto, H.; LeBleu, V.; Xu, X.; Müller, G.A.; Zeisberg, E.M.; Kalluri, R.; Zeisberg, M. Tet3-Mediated Hydroxymethylation of Epigenetically Silenced Genes Contributes to Bone Morphogenic Protein 7-Induced Reversal of Kidney Fibrosis. J. Am. Soc. Nephrol. 2014, 25, 905-912. [CrossRef] [PubMed]

68. Miao, F.; Chen, Z.; Genuth, S.; Paterson, A.; Zhang, L.; Wu, X.; Li, S.M.; Cleary, P.; Riggs, A.; Harlan, D.M.; et al. Evaluating the Role of Epigenetic Histone Modifications in the Metabolic Memory of Type 1 Diabetes. Diabetes 2014, 63, 1748-1762. [CrossRef]

69. Yuan, H.; Reddy, M.A.; Sun, G.; Lanting, L.; Wang, M.; Kato, M.; Natarajan, R. Involvement of p300/CBP and epigenetic histone acetylation in TGF- $31-$ mediated gene transcription in mesangial cells. Am. J. Physiol. Ren. Physiol. 2013, 304, F601-F613. [CrossRef]

70. Kato, M.; Dang, V.; Wang, M.; Park, J.T.; Deshpande, S.; Kadam, S.; Mardiros, A.; Zhan, Y.; Oettgen, P.; Putta, S.; et al. TGF- $\beta$ induces acetylation of chromatin and of Ets-1 to alleviate repression of miR-192 in diabetic nephropathy. Sci. Signal. 2013, 6, ra43. [CrossRef]

71. Dong, Z. Acetylation of Ets-1 Is the Key to Chromatin Remodeling for miR-192 Expression. Sci. Signal. 2013, 6, pe21. [CrossRef]

72. Kato, M.; Zhang, J.; Wang, M.; Lanting, L.; Yuan, H.; Rossi, J.J.; Natarajan, R. MicroRNA-192 in diabetic kidney glomeruli and its function in TGF- $\beta$-induced collagen expression via inhibition of E-box repressors. Proc. Natl. Acad. Sci. USA 2007, 104, $3432-3437$. [CrossRef] [PubMed]

73. Rerolle, J.-P.; Hertig, A.; Nguyen, G.; Sraer, J.-D.; Rondeau, E.P. Plasminogen activator inhibitor type 1 is a potential target in renal fibrogenesis. Kidney Int. 2000, 58, 1841-1850. [CrossRef]

74. Kuan, C.J.; Al-Douahji, M.; Shankland, S.J. The cyclin kinase inhibitor p21WAF1, CIP1 is increased in experimental diabetic nephropathy: Potential role in glomerular hypertrophy. J. Am. Soc. Nephrol. 1998, 9, 986-993. [CrossRef]

75. Liu, F.; Zong, M.; Wen, X.; Li, X.; Wang, J.; Wang, Y.; Jiang, W.; Li, X.; Guo, Z.; Qi, H. Silencing of Histone Deacetylase 9 Expression in Podocytes Attenuates Kidney Injury in Diabetic Nephropathy. Sci. Rep. 2016, 6, 33676. [CrossRef]

76. Wang, X.; Liu, J.; Zhen, J.; Zhang, C.; Wan, Q.; Liu, G.; Wei, X.; Zhang, Y.; Wang, Z.; Han, H.; et al. Histone deacetylase 4 selectively contributes to podocyte injury in diabetic nephropathy. Kidney Int. 2014, 86, 712-725. [CrossRef] [PubMed]

77. Hasegawa, K.; Wakino, S.; Simic, P.; Sakamaki, Y.; Minakuchi, H.; Fujimura, K.; Hosoya, K.; Komatsu, M.; Kaneko, Y.; Kanda, T.; et al. Renal tubular Sirt1 attenuates diabetic albuminuria by epigenetically suppressing Claudin-1 overexpression in podocytes. Nat. Med. 2013, 19, 1496-1504. [CrossRef] [PubMed]

78. Chen, H.; Li, J.; Jiao, L.; Petersen, R.B.; Li, J.; Peng, A.; Zheng, L.; Huang, K. Apelin inhibits the development of diabetic nephropathy by regulating histone acetylation in Akita mouse. J. Physiol. 2013, 592, 505-521. [CrossRef]

79. Sun, G.; Reddy, M.A.; Yuan, H.; Lanting, L.; Kato, M.; Natarajan, R. Epigenetic Histone Methylation Modulates Fibrotic Gene Expression. J. Am. Soc. Nephrol. 2010, 21, 2069-2080. [CrossRef]

80. Chen, J.; Guo, Y.; Zeng, W.; Huang, L.; Pang, Q.; Nie, L.; Mu, J.; Yuan, F.; Feng, B. ER stress triggers MCP-1 expression through SET7/9-induced histone methylation in the kidneys of db/db mice. Am. J. Physiol. Ren. Physiol. 2014, 306, F916-F925. [CrossRef]

81. Lin, S.-H.; Ho, W.-T.; Wang, Y.-T.; Chuang, C.-T.; Chuang, L.-Y.; Guh, J.-Y. Histone methyltransferase Suv39h1 attenuates high glucose-induced fibronectin and p21(WAF1) in mesangial cells. Int. J. Biochem. Cell Biol. 2016, 78, 96-105. [CrossRef]

82. Wang, J.; Yan, W.; Peng, X.; Jiang, Y.; He, L.; Peng, Y.; Chen, X.; Ye, M.; Zhuo, H. Functional Role of SUV39H1 in Human Renal Tubular Epithelial Cells Under High-glucose Ambiance. Inflammation 2018, 41, 1-10. [CrossRef]

83. Goru, S.K.; Kadakol, A.; Pandey, A.; Malek, V.; Sharma, N.; Gaikwad, A.B. Histone H2AK119 and H2BK120 mono-ubiquitination modulate SET7/9 and SUV39H1 in type 1 diabetes-induced renal fibrosis. Biochem. J. 2016, 473, 3937-3949. [CrossRef]

84. Siddiqi, F.S.; Majumder, S.; Thai, K.; Abdalla, M.; Hu, P.; Advani, S.L.; White, K.E.; Bowskill, B.B.; Guarna, G.; dos Santos, C.C.; et al. The Histone Methyltransferase Enzyme Enhancer of Zeste Homolog 2 Protects against Podocyte Oxidative Stress and Renal Injury in Diabetes. J. Am. Soc. Nephrol. 2016, 27, 2021-2034. [CrossRef]

85. Majumder, S.; Thieme, K.; Batchu, S.N.; Alghamdi, T.A.; Bowskill, B.B.; Kabir, M.G.; Liu, Y.; Advani, S.L.; White, K.E.; Geldenhuys, L.; et al. Shifts in podocyte histone H3K27me3 regulate mouse and human glomerular disease. J. Clin. Investig. 2017, 128, 483-499. [CrossRef] [PubMed]

86. Jia, Y.; Reddy, M.A.; Das, S.; Oh, H.J.; Abdollahi, M.; Yuan, H.; Zhang, E.; Lanting, L.; Wang, M.; Natarajan, R. Dysregulation of histone $\mathrm{H} 3$ lysine 27 trimethylation in transforming growth factor- $\beta 1$-induced gene expression in mesangial cells and diabetic kidney. J. Biol. Chem. 2019, 294, 12695-12707. [CrossRef] [PubMed]

87. Sun, Y.; Peng, R.; Peng, H.; Liu, H.; Wen, L.; Wu, T.; Yi, H.; Li, A.; Zhang, Z. MiR-451 suppresses the NF-kappaB-mediated proinflammatory molecules expression through inhibiting LMP7 in diabetic nephropathy. Mol. Cell. Endocrinol. 2016, 433, 75-86. [CrossRef]

88. Bhatt, K.; Lanting, L.L.; Jia, Y.; Yadav, S.; Reddy, M.A.; Magilnick, N.; Boldin, M.; Natarajan, R. Anti-Inflammatory Role of MicroRNA-146a in the Pathogenesis of Diabetic Nephropathy. J. Am. Soc. Nephrol. 2016, 27, 2277-2288. [CrossRef] [PubMed] 
89. Lee, H.W.; Khan, S.Q.; Khaliqdina, S.; Altintas, M.M.; Grahammer, F.; Zhao, J.L.; Koh, K.H.; Tardi, N.J.; Faridi, M.H.; Geraghty, T.; et al. Absence of miR-146a in Podocytes Increases Risk of Diabetic Glomerulopathy via Up-regulation of ErbB4 and Notch-1. J. Biol. Chem. 2017, 292, 732-747. [CrossRef]

90. Deshpande, S.D.; Putta, S.; Wang, M.; Lai, J.Y.; Bitzer, M.; Nelson, R.G.; Lanting, L.L.; Kato, M.; Natarajan, R. Transforming growth factor- $\beta$-induced cross talk between p53 and a microRNA in the pathogenesis of diabetic nephropathy. Diabetes 2013, 62 , 3151-3162. [CrossRef]

91. Putta, S.; Lanting, L.; Sun, G.; Lawson, G.; Kato, M.; Natarajan, R. Inhibiting MicroRNA-192 Ameliorates Renal Fibrosis in Diabetic Nephropathy. J. Am. Soc. Nephrol. 2012, 23, 458-469. [CrossRef] [PubMed]

92. Krupa, A.; Jenkins, R.; Luo, D.D.; Lewis, A.; Phillips, A.; Fraser, D. Loss of MicroRNA-192 Promotes Fibrogenesis in Diabetic Nephropathy. J. Am. Soc. Nephrol. 2010, 21, 438-447. [CrossRef]

93. Lin, C.-L.; Lee, P.-H.; Hsu, Y.-C.; Lei, C.-C.; Ko, J.-Y.; Chuang, P.-C.; Huang, Y.-T.; Wang, S.-Y.; Wu, S.-L.; Chen, Y.-S.; et al. MicroRNA-29a Promotion of Nephrin Acetylation Ameliorates Hyperglycemia-Induced Podocyte Dysfunction. J. Am. Soc. Nephrol. 2014, 25, 1698-1709. [CrossRef]

94. Chen, H.Y.; Zhong, X.; Huang, X.R.; Meng, X.-M.; You, Y.; Chung, A.C.; Lan, H.Y. MicroRNA-29b Inhibits Diabetic Nephropathy in $\mathrm{db} / \mathrm{db}$ Mice. Mol. Ther. 2014, 22, 842-853. [CrossRef] [PubMed]

95. Sun, S.F.; Tang, P.M.K.; Feng, M.; Xiao, J.; Huang, X.R.; Li, P.; Ma, R.C.W.; Lan, H.Y. Novel lncRNA Erbb4-IR Promotes Diabetic Kidney Injury in $\mathrm{db} / \mathrm{db}$ Mice by Targeting miR-29b. Diabetes 2017, 67, 731-744. [CrossRef]

96. Long, J.; Wang, Y.; Wang, W.; Chang, B.H.J.; Danesh, F.R. MicroRNA-29c is a signature microRNA under high glucose con-ditions that targets Sprouty homolog 1, and its in vivo knockdown prevents progression of diabetic nephropathy. J. Biol. Chem. 2011, 286, 11837-11848. [CrossRef] [PubMed]

97. Zhang, X.; Song, S.; Luo, H. Regulation of podocyte lesions in diabetic nephropathy via miR-34a in the Notch signaling pathway. Medicine 2016, 95, e5050. [CrossRef] [PubMed]

98. Liu, X.-D.; Zhang, L.-Y.; Zhu, T.-C.; Zhang, R.-F.; Wang, S.-L.; Bao, Y. Overexpression of miR-34c inhibits high glucose-induced apoptosis in podocytes by targeting Notch signaling pathways. Int. J. Clin. Exp. Pathol. 2015, 8, 4525-4534. [PubMed]

99. Li, A.; Peng, R.; Sun, Y.; Liu, H.; Peng, H.; Zhang, Z. LincRNA 1700020I14Rik alleviates cell proliferation and fibrosis in diabetic nephropathy via miR-34a-5p/Sirt1/HIF-1 $\alpha$ signaling. Cell Death Dis. 2018, 9, 461. [CrossRef] [PubMed]

100. Wang, J.; Duan, L.; Tian, L.; Liu, J.; Wang, S.; Gao, Y.; Yang, J. Serum miR-21 may be a Potential Diagnostic Biomarker for Diabetic Nephropathy. Exp. Clin. Endocrinol. Diabetes 2016, 124, 417-423. [CrossRef] [PubMed]

101. McClelland, A.D.; Herman-Edelstein, M.; Komers, R.; Jha, J.C.; Winbanks, C.E.; Hagiwara, S.; Gregorevic, P.; Kantharidis, P.; Cooper, M.E. MiR-21 promotes renal fibrosis in diabetic nephropathy by targeting PTEN and SMAD7. Clin. Sci. 2015, 129, 1237-1249. [CrossRef]

102. Park, J.T.; Kato, M.; Yuan, H.; Castro, N.; Lanting, L.; Wang, M.; Natarajan, R. FOG2 protein down-regulation by transforming growth factor- $\beta 1$-induced microRNA-200b/c leads to Akt kinase activation and glomerular mesangial hypertrophy related to diabetic nephropathy. J. Biol. Chem. 2013, 288, 22469-22480. [CrossRef] [PubMed]

103. He, F.; Peng, F.; Xia, X.; Zhao, C.; Luo, Q.; Guan, W.; Li, Z.; Yu, X.; Huang, F. MiR-135a promotes renal fibrosis in diabetic nephropathy by regulating TRPC1. Diabetologia 2014, 57, 1726-1736. [CrossRef]

104. Wang, Q.; Wang, Y.; Minto, A.W.; Wang, J.; Shi, Q.; Li, X.; Quigg, R.J. MicroRNA-377 is up-regulated and can lead to increased fibronectin production in diabetic nephropathy. FASEB J. 2008, 22, 4126-4135. [CrossRef] [PubMed]

105. Koga, K.; Yokoi, H.; Mori, K.; Kasahara, M.; Kuwabara, T.; Imamaki, H.; Ishii, A.; Mori, K.P.; Kato, Y.; Ohno, S.; et al. MicroRNA26a inhibits TGF- $\beta$-induced extracellular matrix protein expression in podocytes by targeting CTGF and is downregulated in diabetic nephropathy. Diabetologia 2015, 58, 2169-2180. [CrossRef]

106. Wang, B.; Jha, J.C.; Hagiwara, S.; McClelland, A.D.; Jandeleit-Dahm, K.; Thomas, M.C.; Cooper, M.E.; Kantharidis, P. Transforming growth factor- $\beta 1$-mediated renal fibrosis is dependent on the regulation of transforming growth factor receptor 1 expression by let-7b. Kidney Int. 2014, 85, 352-361. [CrossRef] [PubMed]

107. Park, J.T.; Kato, M.; Lanting, L.; Castro, N.; Nam, B.Y.; Wang, M.; Kang, S.-W.; Natarajan, R. Repression of let-7 by trans-forming growth factor- $\beta 1$-induced Lin28 upregulates collagen expression in glomerular mesangial cells under diabetic conditions. Am. J. Physiol. Ren. Physiol. 2014, 307, F1390-F1403. [CrossRef]

108. Bai, X.; Geng, J.; Zhou, Z.; Tian, J.; Li, X. MicroRNA-130b improves renal tubulointerstitial fibrosis via repression of Snail-induced epithelial-mesenchymal transition in diabetic nephropathy. Sci. Rep. 2016, 6, 20475. [CrossRef]

109. Wang, B.; Koh, P.; Winbanks, C.; Coughlan, M.T.; McClelland, A.; Watson, A.; Jandeleit-Dahm, K.; Burns, W.C.; Thomas, M.C.; Cooper, M.E.; et al. MiR-200a Prevents renal fibrogenesis through repression of TGF- $\beta 2$ expression. Diabetes 2011, 60, $280-287$. [CrossRef]

110. Gao, J.; Wang, W.; Wang, F.; Guo, C. LncRNA-NR_033515 promotes proliferation, fibrogenesis and epithelial-to-mesenchymal transition by targeting miR-743b-5p in diabetic nephropathy. Biomed. Pharmacother. 2018, 106, 543-552. [CrossRef]

111. Li, X.; Zeng, L.; Cao, C.; Lu, C.; Lian, W.; Han, J.; Zhang, X.; Zhang, J.; Tang, T.; Li, M. Long noncoding RNA MALAT1 regulates renal tubular epithelial pyroptosis by modulated miR-23c targeting of ELAVL1 in diabetic nephropathy. Exp. Cell Res. 2017, 350, 327-335. [CrossRef] 
112. Bai, X.; Geng, J.; Li, X.; Wan, J.; Liu, J.; Zhou, Z.; Liu, X. Long Noncoding RNA LINC01619 Regulates MicroRNA-27a/Forkhead Box Protein O1 and Endoplasmic Reticulum Stress-Mediated Podocyte Injury in Diabetic Nephropathy. Antioxid. Redox Signal. 2018, 29, 355-376. [CrossRef] [PubMed]

113. Kato, M.; Wang, M.; Chen, Z.; Bhatt, K.; Oh, H.J.; Lanting, L.; Deshpande, S.; Jia, Y.; Lai, J.Y.C.; O'Connor, C.L.; et al. An endoplasmic reticulum stress-regulated lncRNA hosting a microRNA mega-cluster induces early features of diabetic nephropathy. Nat. Commun. 2016, 7, 12864. [CrossRef]

114. Alvarez, M.L.; Khosroheidari, M.; Eddy, E.; Kiefer, J. Role of microRNA 1207-5P and its host gene, the long non-coding RNA Pvt1, as mediators of extracellular matrix accumulation in the kidney: Implications for diabetic nephropathy. PLoS ONE 2013, 8, e77468.

115. Cao, X.; Fan, Q.-L. LncRNA MIR503HG Promotes High-Glucose-Induced Proximal Tubular Cell Apoptosis by Targeting miR-5035p/Bcl-2 Pathway. Diabetes Metab. Syndr. Obes. Targets Ther. 2020, 13, 4507-4517. [CrossRef]

116. Rössig, L.; Li, H.; Fisslthaler, B.; Urbich, C.; Fleming, I.; Förstermann, U.; Zeiher, A.M.; Dimmeler, S. Inhibitors of Histone Deacetylation Downregulate the Expression of Endothelial Nitric Oxide Synthase and Compromise Endothelial Cell Function in Vasorelaxation and Angiogenesis. Circ. Res. 2002, 91, 837-844.

117. Takahashi, T.; Harris, R.C. Role of Endothelial Nitric Oxide Synthase in Diabetic Nephropathy: Lessons from Diabetic eNOS Knockout Mice. J. Diabetes Res. 2014, 2014, 590541. [CrossRef] [PubMed]

118. Fu, J.; Wei, C.; Zhang, W.; Schlondorff, D.; Wu, J.; Cai, M.; He, W.; Baron, M.H.; Chuang, P.Y.; Liu, Z.; et al. Gene expression profiles of glomerular endothelial cells support their role in the glomerulopathy of diabetic mice. Kidney Int. 2018, 94, 326-345. [CrossRef] [PubMed]

119. Li, Y.; Ren, D.; Xu, G. Long noncoding RNA MALAT1 mediates high glucose-induced glomerular endothelial cell injury by epigenetically inhibiting klotho via methyltransferase G9a. IUBMB Life 2019, 71, 873-881. [CrossRef]

120. Alghamdi, T.A.; Batchu, S.N.; Hadden, M.J.; Yerra, V.G.; Liu, Y.; Bowskill, B.B.; Advani, S.L.; Geldenhuys, L.; Siddiqi, F.S.; Majumder, S.; et al. Histone H3 Serine 10 Phosphorylation Facilitates Endothelial Activation in Diabetic Kidney Disease. Diabetes 2018, 67, 2668-2681. [CrossRef]

121. Jia, Y.; Guan, M.; Zheng, Z.; Zhang, Q.; Tang, C.; Xu, W.; Xiao, Z.; Wang, L.; Xue, Y. MiRNAs in Urine Extracellular Vesicles as Predictors of Early-Stage Diabetic Nephropathy. J. Diabetes Res. 2016, 2016, 7932765. [CrossRef]

122. Barutta, F.; Tricarico, M.; Corbelli, A.; Annaratone, L.; Pinach, S.; Grimaldi, S.; Bruno, G.; Cimino, D.; Taverna, D.; Deregibus, M.C.; et al. Urinary Exosomal MicroRNAs in Incipient Diabetic Nephropathy. PLoS ONE 2013, 8, e73798. [CrossRef] [PubMed]

123. Al-Kafaji, G.; Al-Mahroos, G.; Al-Muhtaresh, H.A.; Skrypnyk, C.; Sabry, M.A.; Ramadan, A.R. Decreased expression of circulating microRNA-126 in patients with type 2 diabetic nephropathy: A potential blood-based biomarker. Exp. Ther. Med. 2016, 12, 815-822. [CrossRef]

124. Barutta, F.; Bruno, G.; Matullo, G.; Chaturvedi, N.; Grimaldi, S.; Schalkwijk, C.; Stehouwer, C.D.; Fuller, J.H.; Gruden, G. MicroRNA-126 and micro-/macrovascular complications of type 1 diabetes in the EURODIAB Prospective Complications Study. Acta Diabetol. 2017, 54, 133-139. [CrossRef] [PubMed]

125. Cardenas-Gonzalez, M.; Srivastava, A.; Pavkovic, M.; Bijol, V.; Rennke, H.G.; Stillman, I.E.; Zhang, X.; Parikh, S.; Rovin, B.H.; Afkarian, M.; et al. Identification, Confirmation, and Replication of Novel Urinary MicroRNA Biomarkers in Lupus Nephritis and Diabetic Nephropathy. Clin. Chem. 2017, 63, 1515-1526. [CrossRef]

126. Jones, P.A.; Issa, J.-P.; Baylin, S. Targeting the cancer epigenome for therapy. Nat. Rev. Genet. 2016, 17, 630-641. [CrossRef] [PubMed]

127. Zhang, L.; Zhang, Q.; Liu, S.; Chen, Y.; Li, R.; Lin, T.; Yu, C.; Zhang, H.; Huang, Z.; Zhao, X.; et al. DNA methyltransferase 1 may be a therapy target for attenuating diabetic nephropathy and podocyte injury. Kidney Int. 2017, 92, 140-153. [CrossRef]

128. Liu, R.; Zhong, Y.; Li, X.; Chen, H.; Jim, B.; Zhou, M.-M.; Chuang, P.Y.; He, J.C. Role of Transcription Factor Acetylation in Diabetic Kidney Disease. Diabetes 2014, 63, 2440-2453. [CrossRef]

129. Nunez, J.K.; Chen, J.; Pommier, G.C.; Cogan, J.Z.; Replogle, J.M.; Adriaens, C.; Ramadoss, G.N.; Shi, Q.; Hung, K.L.; Samelson, A.J.; et al. Genome-wide programmable transcriptional memory by CRISPR-based epigenome editing. Cell 2021, 184, 2503-2519.e17. [CrossRef]

130. Pulecio, J.; Verma, N.; Mejia-Ramirez, E.; Huangfu, D.; Raya, A. CRISPR/Cas9-Based Engineering of the Epigenome. Cell Stem Cell 2017, 21, 431-447. [CrossRef]

131. Sasso, F.C.; Pafundi, P.C.; Simeon, V.; de Nicola, L.; Chiodini, P.; Galiero, R.; Rinaldi, L.; Nevola, R.; Salvatore, T.; Sardu, C.; et al. Efficacy and durability of multifactorial intervention on mortality and MACEs: A randomized clinical trial in type-2 diabetic kidney disease. Cardiovasc. Diabetol. 2021, 20, 145. [CrossRef]

132. Zelniker, T.A.; Wiviott, S.D.; Raz, I.; Im, K.; Goodrich, E.L.; Bonaca, M.P.; Mosenzon, O.; Kato, E.T.; Cahn, A.; Furtado, R.H.M.; et al. SGLT2 inhibitors for primary and secondary prevention of cardiovascular and renal outcomes in type 2 diabetes: A systematic review and meta-analysis of cardiovascular outcome trials. Lancet 2019, 393, 31-39. [CrossRef] 